\title{
Coffee provides a natural multitarget pharmacopeia against the hallmarks of cancer
}

\author{
François Gaascht $^{1,2} \cdot$ Mario Dicato ${ }^{1} \cdot$ Marc Diederich $^{3}$
}

Received: 15 July 2015/ Accepted: 29 October 2015/Published online: 17 November 2015

(C) Springer-Verlag Berlin Heidelberg 2015

\begin{abstract}
Coffee is the second most popular beverage in the world after water with a consumption of approximately two billion cups per day. Due to its low cost and ease of preparation, it is consumed in almost all countries and by all social classes of the population through different modes of preparation. Despites its simple appearance, a cup of coffee is in fact a complex mixture that contains hundreds of molecules, the composition and concentration of which vary widely and depend on factors including the origin of the coffee tree or its metabolism. Although an excessive consumption of coffee can be harmful, many molecules that are present in this black decoction exert anticancer properties. This review aims to describe the different primary coffee-containing substances that exert chemopreventive and bioactive activities against the different hallmarks and enabling characteristics of cancer, thus explaining the anticancer health benefit of black coffee.
\end{abstract}

Keywords Caffeine - Chemoprevention - Coffea sp., natural products $\cdot$ Melanoidins $\cdot$ Polyphenols

Marc Diederich

marcdiederich@snu.ac.kr

1 Laboratoire de Biologie Moléculaire et Cellulaire du Cancer (LBMCC), Hôpital Kirchberg, 9 Rue Edward Steichen, 2540 Luxembourg, Luxembourg

2 Fundación MEDINA, Centro de Excelencia en Investigación de Medicamentos Innovadores en Andalucía, Avenida del Conocimiento 3, Parque Tecnológico de Ciencias de la Salud, 18016 Armilla, Granada, Spain

3 Department of Pharmacy, College of Pharmacy, Seoul National University, Seoul 151-742, Republic of Korea

\section{Introduction}

Cancer is currently a major public health problem, and the physical or chemical tools used to fight against this frequently fatal disease remain few and, too often, ineffective. The figures recently released by the World Health Organization (WHO) reveal that 14.1 million new cancer cases and 8.2 million cancer-related deaths occurred in 2012 (GLOBOCAN 2012, http://globocan.iarc.fr/pages/fact_ sheets_cancer.aspx. Accessed October 2015). In Europe, more than 1.3 million people are estimated to die of cancer in 2015 (Malvezzi et al. 2015). However, cancer is a preventable disease, and between 25 and $40 \%$ of cancer cases are estimated to be directly related to an unhealthy lifestyle and living in a polluted environment (White et al. 2013).

Cancer is a complex and evolving disease that may have endogenous (genetic) or exogenous (environment) origins and which is triggered by the accumulation of mutations, leading to the transformation of a healthy normal cell into a cancer cell. Carcinogenesis is a slow process that requires several years and occurs in different stages and can be compared to a Darwinian evolution process, where each mutation gives an advantage to the new mutated protein (Heng et al. 2011; Merlo et al. 2006). In 2011, Hanahan and Weinberg proposed a model that suggests that the slow transformation of a normal cell into a cancer cells requires ten cellular physiological rearrangements. These different hallmarks of cancer are (1) sustaining proliferative signaling, (2) evading growth suppressors, (3) reprogramming energy metabolism, (4) inducing angiogenesis, (5) activating invasion and metastasis, (6) enabling replicative immortality, (7) evading immune destruction, (8) resisting cell death and the two enabling characteristics that constitute the cornerstone of carcinogenesis: (9) genome instability that provide mutations and (10) inflammation 
that results in signaling molecules and growth factors (Hanahan and Weinberg 2011).

Used empirically in traditional medicine for thousands of years without fully knowing their mechanisms of action, natural products from marine or terrestrial organisms feature a wide variability of chemical structures that modulate a wide range of biological effects (Cerella et al. 2014; Morceau et al. 2015; Schnekenburger et al. 2014, 2015; Schumacher et al. 2011). These compounds act on a number of therapeutic targets, including processes involved in cancer development and progression (Gaascht et al. 2010; Lee et al. 2015; Muller et al. 2015; Sawadogo et al. 2012, 2015; Teiten et al. 2013). Among the vast natural chemical library, we can note isolated plant substances, such as curcumin (Teiten et al. 2010, 2011), aurones (Zwergel et al. 2012), plumbagin (Gaascht et al. 2014) and fungal secondary metabolites embellicines (Ebrahim et al. 2013), which were recently investigated for their chemopreventive and anticancer properties.

According to a legend, Kaldi, a goat herder living in Abyssinia or current-day Northern Ethiopia discovered coffee when he noticed the excited nature of his goats after they had consumed the red berries that had fallen from a shrub. Surprised by the power of these berries, he brought them to a monk who, frightened of their effect and thinking that these berries were Devil's fruits, threw the berries into the fire. After a few minutes in the fire, the coffee beans released a pleasant aroma that intrigued the monk, who decided to remove the seeds from the fire, grind and immerse them in water to preserve their stimulating properties to help monks stay awake during their long nightly sessions of prayers (Bond 2011). Today, coffee is produced mainly by two species of Coffea ( $C$. arabica and $C$. canephora syn. $C$. robusta) in the tropical regions of the world, and over 546,000 tons were exported by more than 48 coffee-producing countries in August 2015 (International Coffee Organization, http://www.ico.org/prices/m3exports.pdf. Accessed October 2015). With an estimated consumption of more than two billion cups per day, coffee has become the most widely drunk beverage in the world after water. With this popularity, coffee has become the first cash crop in the world and the second most traded commodity after oil, and its price is reevaluated every day (International Coffee Organization, http://www.ico.org/ coffee_prices.asp. Accessed October 2015).

\section{A pharmacy in your cup}

A cup of coffee is a complex mixture of several hundred molecules whose concentration and composition depend on many parameters: Water is the most abundant molecule in a cup of coffee and plays the role of solvent in the extraction of the compounds present in coffee. These diversified compounds include chemical elements, amino acids, polyphenols, acids, diterpenes, melanoidins, lipids and sugars (Fig. 1) (Pohl et al. 2013; Rodrigues and Bragagnolo 2013). No less than 1000 volatile compounds are generated during the roasting process, and between 25 and 35 are responsible for the coffee aroma (Mestdagh et al. 2014). Thus, many factors that change from the harvest of green coffee beans to the consumption of a steaming cup of coffee influence the metabolome of this beverage: Coffee plant species (genetic factor) (Kitzberger et al. 2014) as well as geographical origin and growing conditions (climate, altitude, light, soil, temperature...) (Wei et al. 2012a), diseases and symbiosis (pest and fungi) (Sbrana et al. 2014), harvesting (period), fruit development (Sridevi and Parvatam 2013), drying (dry or wet method) (Duarte et al. 2010), roasting process (duration, shaking, temperature, sugar addition) (Ludwig et al. 2013a; Wei et al. 2012b), grinding, storage (duration, conditions) (Belviso et al. 2014; Yeretzian et al. 2012) and coffee-making and serving techniques (process, time, hot or cold water, additives...) (Afify et al. 2011; Andueza et al. 2009; Caporaso et al. 2014; Durak et al. 2014; Ludwig et al. 2012; Tagliazucchi et al. 2012) are factors known to influence and modulate the chemical composition of a cup of coffee ready for consumption. Finally, after ingestion, the native coffee metabolites are degraded and modified by the gut microbiome and endogenous enzymes during the digestion process to generate new bioactive compounds (Fig. 2) (Ludwig et al. 2013b; Redeuil et al. 2011).

The first structure that comes to mind is certainly caffeine (Fig. 1). Isolated in 1820 from coffee beans, it is also naturally found in kola nuts (Cola acuminate), cocoa beans (Theobroma cacao), tea leaves (Camellia sinensis) or citrus (Citrus sp.). In plants, it acts as a repellent and protective agent against pests and pathogens, but it also secures secure pollinator fidelity in flowers (Wright et al. 2013). Caffeine (1,3,7-trimethylxanthine) is mainly known for its ability to increase blood pressure and its psychostimulatory and diuretic properties. It is a xanthine alkaloid, a secondary metabolite derived from guanine, and similar to theobromine, it is also present in tea, cocoa and coffee (Mejia and Ramirez-Mares 2014). As previously mentioned, its concentration in coffee beverages depends on many factors. Coffee roasting, the process that consists of the heating of green coffee beans to transform them into black coffee beans decreases the concentration of caffeine (Fig. 2) (Hečimović et al. 2011; Wei et al. 2012b). Moreover, caffeine can also be removed from coffee to provide decaffeinated coffee. Brewing techniques also strongly affect the caffeine quantity; a cup of espresso $(25 \mathrm{~mL})$ contains approximately $60.25 \mathrm{mg}$ of caffeine $(2.44 \mathrm{mg} /$ $\mathrm{mL})$, whereas a mug of filtered coffee $(125 \mathrm{~mL})$ prepared 
(a)<smiles>Cn1c(=O)c2c(ncn2C)n(C)c1=O</smiles>

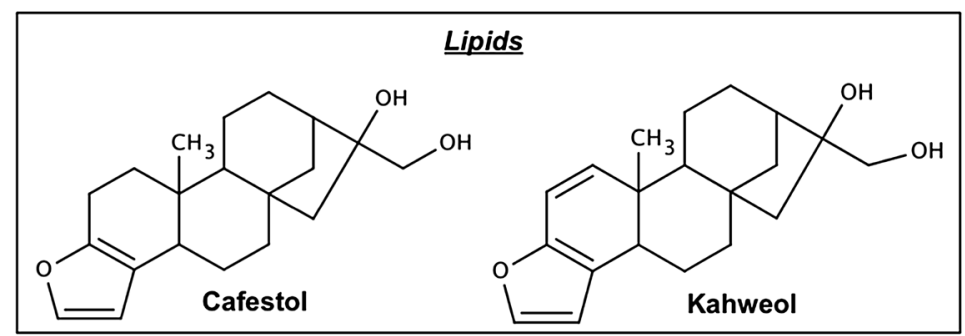

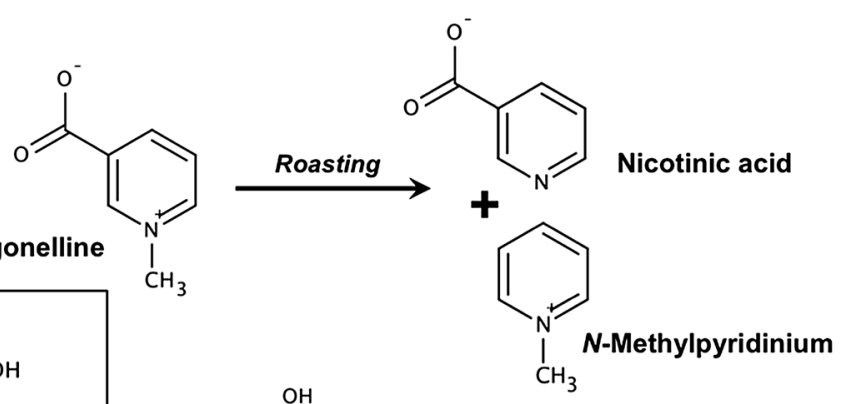

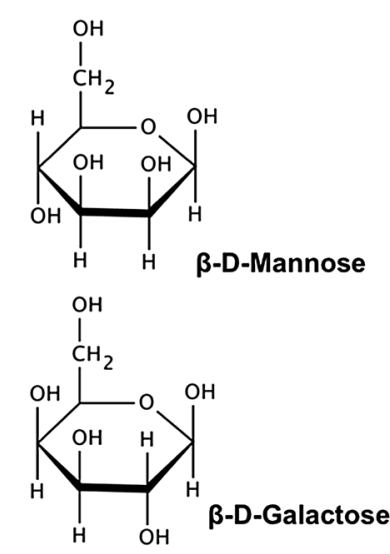

Polysaccharides<smiles>Oc1ccc(O)c(O)c1</smiles>

Hydroxyhydroquinone<smiles>O=CC1CCC(CO)O1</smiles>

5-Hydroxymethylfurfural
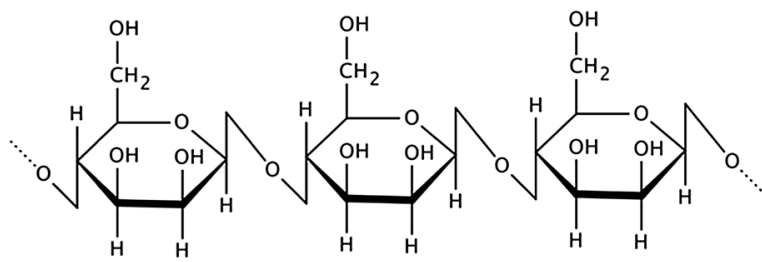

Backbone of galactomannans

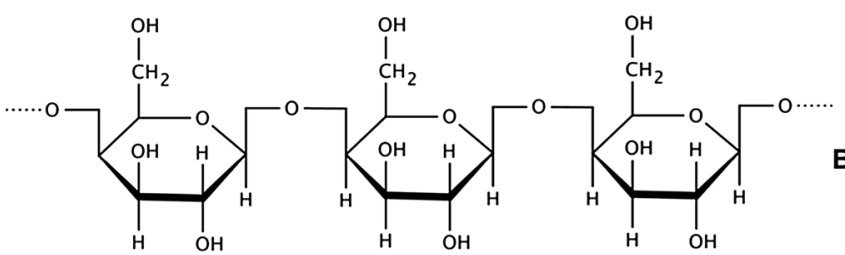

Backbone of arabinogalactans

(b)

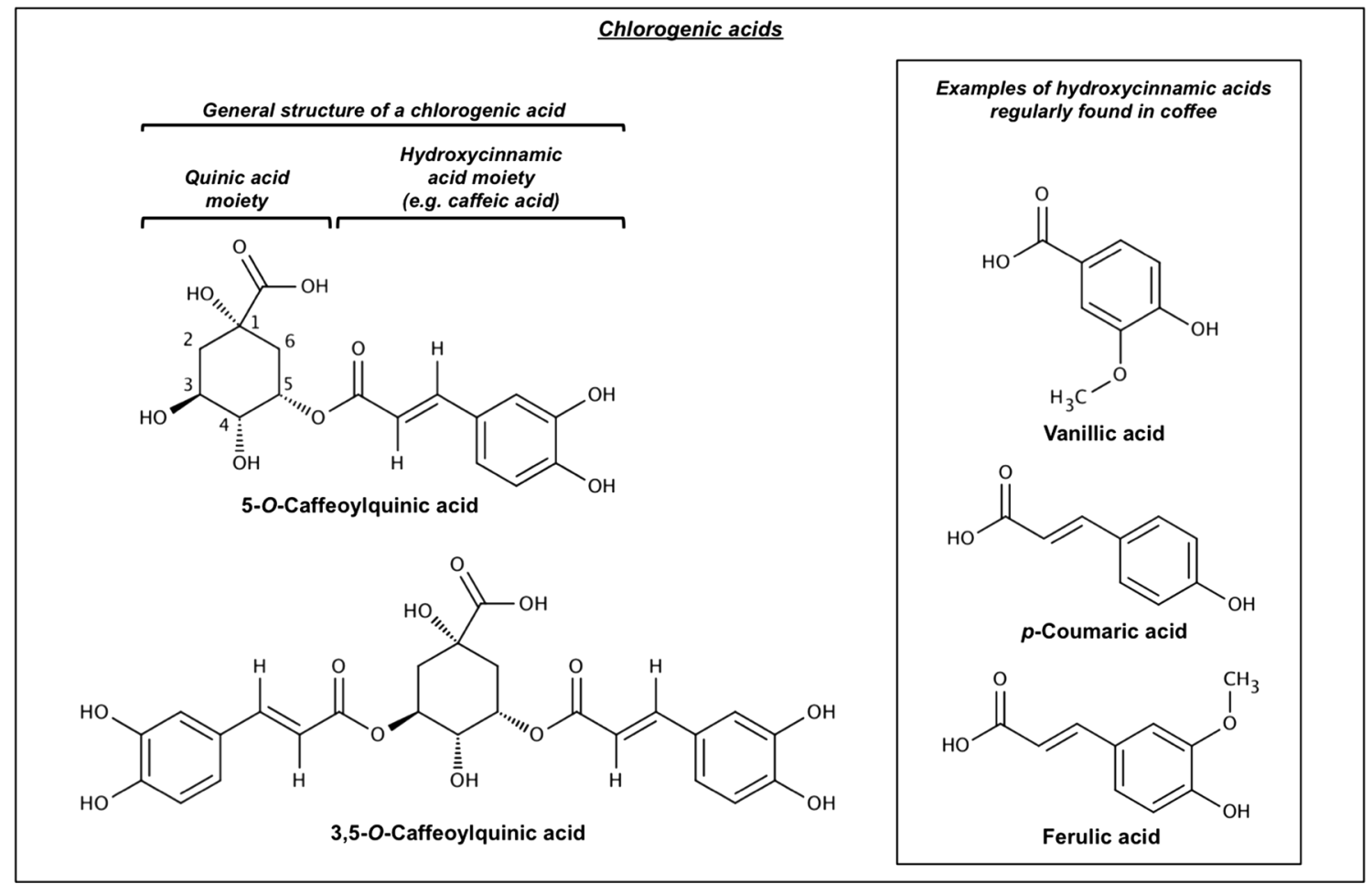


4Fig. 1 Chemical structures of main anticancer compounds present in coffee and their constituents. Marvin was used to draw and display chemical structures, substructures and reactions, Marvin 14.10.20, 2014, ChemAxon (http://www.chemaxon.com)

with the same coffee contains $173.25 \mathrm{mg}(1.39 \mathrm{mg} / \mathrm{mL})$ (Caporaso et al. 2014).

Trigonelline (1-methylpyridinium-3-carboxylate) (Fig. 1) is an alkaloid with phytoestrogen activity whose concentration increases as the coffee fruit develops (Sridevi and Parvatam 2013). Trigonelline is abundant in green coffee beans and partially pyrolyzed into nicotinic acid and $\mathrm{N}$-methylpyridinium (Fig. 1) during roasting process (Fig. 2) (Wei et al. 2012b).

Phenols and polyphenols are a heterogeneous group of secondary metabolites found in plants; these compounds primarily defend against pathogens and environmental factors (Ebrahim et al. 2013). The most abundant group of phenolic compounds identified in coffee consists of approximately 45 different compounds known as chlorogenic acids (CGA), which are formed by an esterified quinic acid moiety and one or several hydroxycinnamic acid moieties, such as caffeic, ferulic, $p$-coumaric, vanillic acid (Fig. 1) (Mills et al. 2013; Mullen et al. 2011;
Somporn et al. 2011). Roasting reduces the initial concentrations of phenolic compounds; therefore, CGAs are more abundant in green coffee beans. However, we cannot strictly comment on this loss because some of these compounds undergo biotransformation, such as hydrolysis and esterification, or are used to form new compounds, such as chlorogenic acid derivatives and melanoidins. The actions of the gut microbiome and enzymes during the digestion process also release various phenolic compounds (Ludwig et al. 2013b; Redeuil et al. 2011). Preparing coffee with a filter decreases the total phenol content and thus the antioxidant capacity of coffee (Fig. 2) (Niseteo et al. 2012).

A cup of coffee also contains lipids, which are mainly found in the form of two diterpene alcohols: cafestol and kahweol (Fig. 1). These molecules are sensitive to the roasting process and also largely removed from coffee when it is brewed using a paper filter (Fig. 2) (Silva et al. 2012).

Arabinogalactans and galactomannans (Fig. 1) are complex polysaccharides that comprise approximately $20 \%$ of the dry weight of green coffee beans and serve as an energy source for germination. Galactomannans consist of a linear backbone of D-mannose residues substituted with side chains of single D-galactose residues. In
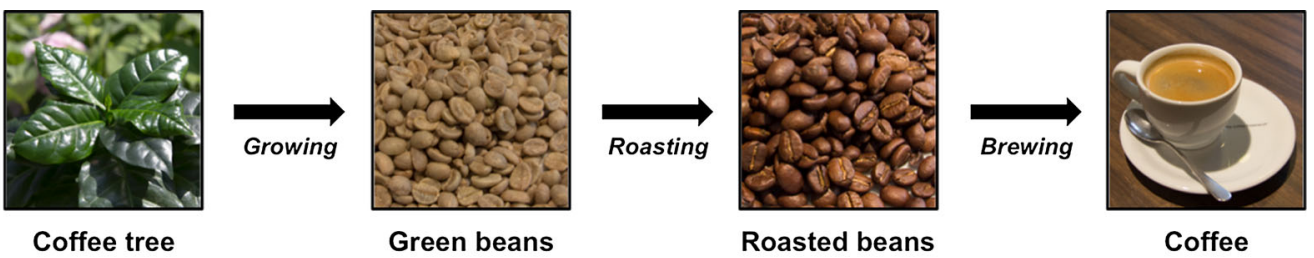

Roasted beans

Coffee

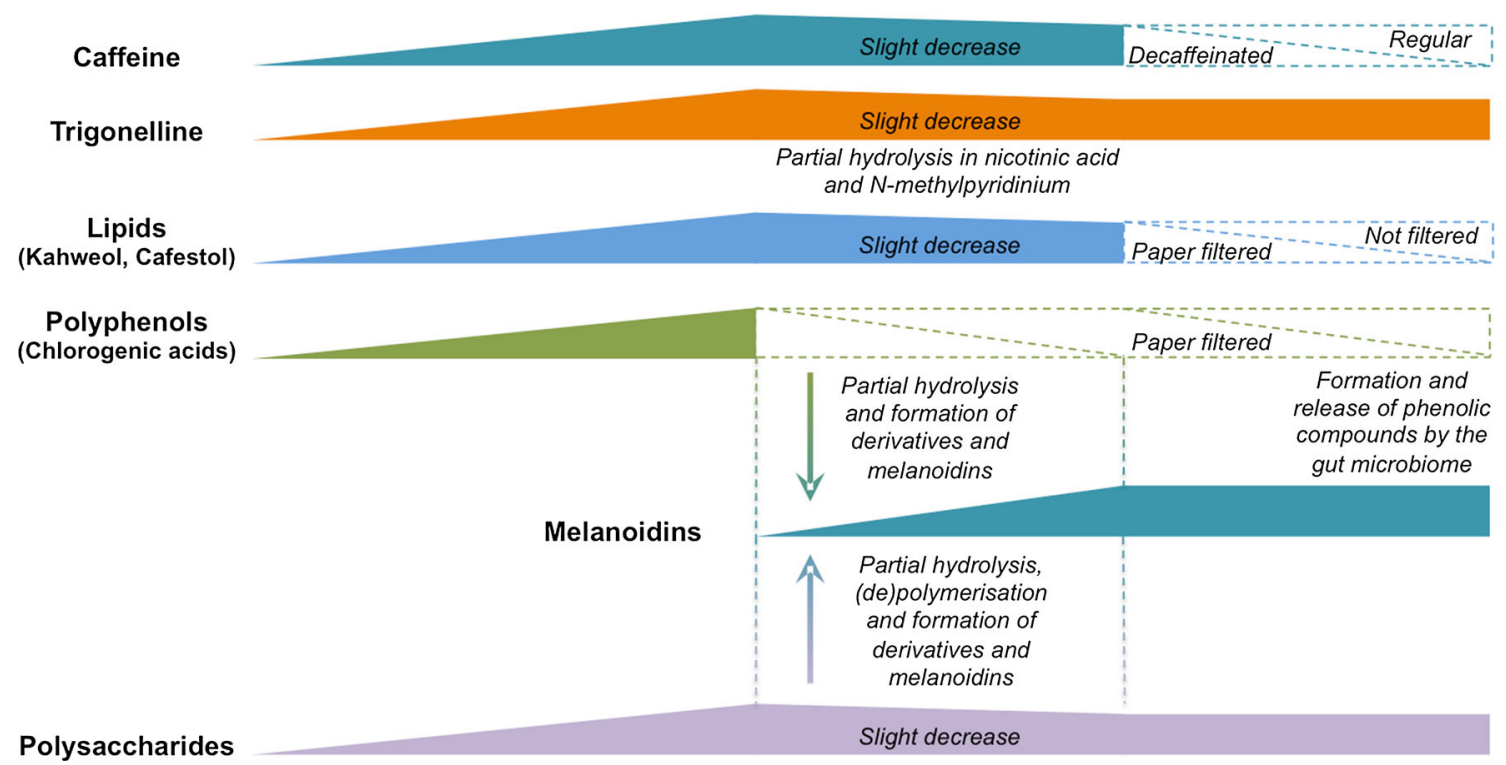

Fig. 2 Trend lines of the main classes of coffee natural products during the different major steps of maturation and preparation. This original figure is a compilation of data obtained from different articles
(Hečimović et al. 2011; Matulova et al. 2011; Mills et al. 2013; Moreira et al. 2012; Mullen et al. 2011; Silva et al. 2012; Somporn et al. 2011; Wei et al. 2012b) 
arabinogalactans, a linear chain of D-galactose residues is substituted by linear chains of D-galactose and D-arabinose. Combinations of polysaccharides can also include proteins (arabinogalactan proteins) and other functional groups (acetyl, glucuronic acid...). During roasting, polysaccharides tend to degrade and become less branched (depolymerisation); however, they can also polymerize and be modified to form melanoidins (Fig. 2) (Matulova et al. 2011; Moreira et al. 2012).

Melanoidins are heterogeneous complex polymeric macromolecules that are predominantly responsible for the dark brown color of coffee and black beer, soy sauce or balsamic vinegar; they are also present in bakery products. Produced by the Maillard reaction during roasting and heating processes, they are the product of the reaction of reducing polysaccharides (arabinogalactans and galactomannans) (Fig. 1), free amino groups from amino acids or proteins and phenolic compounds, mainly chlorogenic acids (Fig. 2) (Perrone et al. 2012). With a molecular weight of up to several kilodaltons $(>10 \mathrm{kDa})$, melanoidins exert several biological functions, such as antimicrobial, antihypertensive, antioxidative, anti-cariogenic or anti-inflammatory activities (Moreira et al. 2012).

\section{Coffee compounds as anticancer agents}

As described above, coffee is a complex mixture whose composition and concentration of molecules depend on multiple factors, from growing to brewing. For this review, we will focus our analysis on the chemopreventive and anticancer potential of bioactive molecules that target the hallmarks of cancer described by Hanahan and Weinberg (Hanahan and Weinberg 2011) and which are theoretically present in a standard cup of black coffee, without taking into account the type of coffee used (origin, grinding...), the mode of preparation or consumption.

\section{Anti-genotoxic, antioxidant and pro-oxidant agents}

The transformation of a normal cell into a cancer cell is based on the acquisition of several hallmarks that thrive due to the accumulation of multiple mutations provided by genomic instability. Genomic instability is based primarily on a greater exposure and increased sensitivity to mutagens, as well as on inefficient DNA integrity control systems, such as cell cycle checkpoints control tools (p53) or the DNA-repair machinery (BRCA) (Negrini et al. 2010). Reactive oxygen species (ROS) are essential mediators in cellular communication, and they act by regulating biological processes including inflammation, proliferation and cell differentiation. Although ROS are essential for cell survival, large quantities of ROS may damage cells and result in DNA mutations or the oxidation of lipids and proteins (Liou and Storz 2010). From a cancer therapeutic view, driver mutations are responsible for the appearance and progression of cancer, and anti-ROS agents that prevent this damage, such as antioxidants, are attested chemopreventive compounds. However, anticancer therapies (drugs, irradiation) that induce mutations or irreversible DNA damage are also commonly used, and these approaches may also kill healthy cells. Moreover, cancer cells grow under the pressure of permanent oxidative stress and are closer to the lethal threshold than healthy cells. Thus, pro-oxidant compounds can also be considered as therapeutic drugs to selectively induce the death of cancer cells (Trachootham et al. 2009).

In this context, various analyses and experiments have underlined the high antioxidant potential of a simple cup of coffee (Caporaso et al. 2014; Rodrigues et al. 2013; Vicente et al. 2014). Two aqueous extracts prepared from C. arabica and robusta spent coffee by Bravo et al. significantly reduced the basal intracellular ROS level in HeLa cells after two hours of treatment starting from a concentration of $37 \mu \mathrm{g} / \mathrm{mL}$. Moreover, the same team reported that a concentration of $1000 \mu \mathrm{g} / \mathrm{mL}$ prevents $\mathrm{H}_{2} \mathrm{O}_{2}$-induced ROS generation in a time- and dose-dependent manner, and a $24 \mathrm{~h}$ pre-treatment with $111 \mu \mathrm{g} / \mathrm{mL}$ of the same extracts protected against DNA damage (Bravo et al. 2013). It has also been shown that a daily consumption of $750 \mathrm{~mL}$ of coffee during 4 weeks significantly decreases spontaneous DNA strand breaks in peripheral white blood cells (Bakuradze et al. 2015). This strong antioxidant and anti-genotoxic potential of coffee is regularly correlated with the presence of numerous phenolic compounds and melanoidins, molecules widely known and described as ROS scavengers (Cheong et al. 2013; Niseteo et al. 2012; Perrone et al. 2012; Rodrigues et al. 2013; Troup et al. 2015). Further studies showed that the melanoidin fraction from instant coffee possesses antioxidant activity and protects against lipid peroxidation and oxidative DNA damage (Del Pino-Garcia et al. 2012).

By analyzing the effects of the consumption of coffee by rats, Ferk et al. (2014) noticed that coffee consumption prevents DNA damage and that this protective effect is stronger when the coffee is prepared using a metal filter, which releases more caffeine, cafestol and kahweol (Fig. 1). The two coffee lipids, cafestol and kahweol, are anti-genotoxic compounds that prevent the deleterious effects of reference carcinogens $N$-nitrosodimethylamine, 2-amino-1-methyl-6-phenylimidazo[4,5-b]pyridine, ferric ion-nitrilotriacetic acid and $\mathrm{H}_{2} \mathrm{O}_{2}$ in human hepatoma HepG2 cells (Majer et al. 2005), NIH/3T3 mouse embryo fibroblast cell line (Lee and Jeong 2007) and healthy human lymphocytes (Bichler et al. 2007). They act directly as ROS scavengers, and they increase the level of UDP- 
glucuronosyltransferase and glutathione $S$-transferase (GST), two enzymes involved in the detoxification of DNA-reactive metabolites. In addition, they act also on the DNA-repair machinery by activating the induction of $O-6$ methylguanine-DNA methyltransferase, a DNA-repair enzyme (Huber et al. 2003). In a more recent study, both cafestol and kahweol were also described as inhibitors of cytochrome P450, an enzyme responsible, among other things, for the activation of carcinogens and thus DNA damage (Silva et al. 2012).

Caffeine (Fig. 1) is a compound that inhibits the reparation of DNA double-strand breaks in HeLa cells by acting on two nucleases (Sae2, Dna2) involved in the DNArepair machinery at the resection step (Tsabar et al. 2015). It is also an inhibitor of ataxia telangiectasia mutated (ATM) and ATM-related (ATR), two sensor kinases activated by DNA double-strand breaks inducing a cell cycle arrest in DNA damage response pathway in breast cancer cell lines (Alao and Sunnerhagen 2009).

Chlorogenic and caffeic acids (Fig. 1) are two coffee phenolic compounds that exert antioxidant activities, although caffeic acid is more potent than chlorogenic acid (Bufalo et al. 2013; Sato et al. 2011). The ability of the caffeine and chlorogenic acids 5- $O$-caffeoylquinic acid (5CQA) and 3,5-O-dicaffeoylquinic acid (3,5-DCQA) (Fig. 1) to protect against ROS-induced oxidation has also been investigated in HepG2 cancer cells. Except for caffeine, a concentration of $1 \mu \mathrm{M}$ of both hydroxycinnamic acids is sufficient to decrease the basal ROS level. Tertbutyl hydroperoxide $(t-\mathrm{BOOH})$, a pro-oxidant and glutathione (GSH)-depleting agent, remains ineffective in HepG2 cells pre-treated with all compounds. However, only the two phenolic acids can recover GSH depletion and reverse the activities of the two antioxidant enzymes GPx (glutathione peroxidase) and GR (glutathione reductase). A concentration of $10 \mu \mathrm{M}$ of the same compounds also prevented lipid and protein oxidation, whereas caffeine did not exert a protective effect (Baeza et al. 2014).

Ferulic acid (Fig. 1), another phenolic chlorogenic acid, inhibits gamma radiation-induced DNA strand breaks and sepsis-induced oxidative damage, enhances the survival of rodent models and increases GSH levels and SOD (superoxide dismutase) and GPx activities (Bacanlı et al. 2014; Maurya and Devasagayam 2013). In human cells, it prevents ultraviolet (UV)-B radiation-induced oxidative DNA damage (Ambothi and Nagarajan 2014).

Several phenolic compounds that also exert genoprotective activities have been described as pro-oxidants and inducers of DNA damage. Thus, caffeic acid (Fig. 1), which has mainly been described as an antioxidant phenolic compound, can decompose and act as a pro-oxidant when coffee is stored in a thermos (Andueza et al. 2009). Chlorogenic acid (Fig. 1) alone induces DNA damage via the formation of topoisomerase I- and topoisomerase IIDNA complexes, more strong in lung cancer cells than in normal lung fibroblasts. Therefore, the level of hydrogen peroxide seems to inhibit the DNA damage induction by chlorogenic acid (Burgos-Moron et al. 2012).

\section{Anti-inflammatory agents}

Inflammation is an immune defense response of an organism in response to an attack, such as pathogen invasion or injury. This natural reaction initiates a complex system based on immune cells and the secretion of mediators, such as factors that regulate angiogenesis, invasion, tissue growth and cell proliferation, which in normal conditions allow the reconstruction and restoration of healthy tissue. However, chronic infections and inflammation are regularly associated with cancer development. In a chronically inflamed or tumor microenvironment, the presence of autocrine and exocrine cytokines, pro-survival and proangiogenic factors stimulates cell activity. In the case of cancer, the nuclear factor- $\kappa \mathrm{B}(\mathrm{NF}-\kappa \mathrm{B})$ and signal transducer and activator of transcription (STAT)-3 signaling pathways, which are mutated or constitutively activated by TNF- $\alpha$ (tumor necrosis factor- $\alpha$ ), induce the expression of growth factors (VEGF, vascular endothelial growth factor), pro-survival factors [B cell lymphoma (Bcl)-2, Bcl-xL] and cytokines, such as interleukin (IL)-8 (Grivennikov et al. 2010; Hanahan and Weinberg 2011).

A study conducted on 84 healthy volunteers aimed to demonstrate the effect of coffee on obesity and revealed that the regular consumption of coffee significantly decreases the transcription of the inflammatory genes NFE2-related factor (Nrf)2, peroxisome proliferator-activated receptor (PPAR) $\gamma$ and IL-6. Using two different types of coffee of known composition, the authors concluded after an analytical study that the anti-inflammatory effect observed correlated with the presence of chlorogenic acids and their metabolites (Winkler et al. 2014). This conclusion is strengthened by a previous study, which analyzed the anti-inflammatory and antioxidant effects of aqueous extracts of green and roasted coffee beans in rodent models. The results showed that the antioxidant activity of the extracts is higher than that of the reference compounds ascorbic acid and butylated hydroxytoluene and that this and the anti-inflammatory effect are likely due to the presence of flavonoids and chlorogenic acids (Moreira et al. 2013).

Treatment with 75 and $25 \mu \mathrm{M}$ of the diterpene kahweol (Fig. 1), respectively, reduced the expression of cyclooxygenase-2 (COX-2), a pro-inflammatory enzyme, and the secretion of monocyte chemo-attractant protein 1 (MCP-1), an inflammatory regulator, in human umbilical vein endothelial cells (HUVEC) (Cardenas et al. 2011). 
Treating MDA-MB-231 cells with $10 \mu \mathrm{M}$ of this compound inhibits the constitutive phosphorylation and transcriptional activity of STAT-3, a transcription factor involved in inflammation, proliferation and angiogenesis (Kim et al. 2012).

A chlorogenic acid (5-O-caffeoylquinic acid) and $\mathrm{N}$ methylpyridinium, a roasting degradation product of trigonelline (Fig. 1), were identified as inducers of the Nrf2/ antioxidant-response element (ARE) detoxifying pathway that lead to an increase in the GST enzyme activity in vitro and in vivo. A study of healthy volunteers confirmed these results, but showed substantial inter-individual variations (Boettler et al. 2011; Volz et al. 2012).

Both chlorogenic acid and caffeic acid (Fig. 1), two phenolic compounds, were reported to inhibit the inducedTLR4 (toll-like receptor 4 )/NF- $\kappa \mathrm{B}$ signaling pathways by preventing inhibitor of kappaB (IкB) $\alpha$ degradation via phosphorylation and thus the expression of target genes, such as TLR4 itself, iNOS (inducible nitric oxide synthase), COX-2, TNF- $\alpha$ and IL-6 (Bufalo et al. 2013; Hwang et al. 2014; Kwak et al. 2013; Shi et al. 2013).

Caffeine (Fig. 1) decreases the secretion of the pro-inflammatory cytokines IL-1ra (interleukin-1 receptor antagonist) and IL-10 by cancer cell-stimulated PBMCs (peripheral blood mononuclear cells) (Bessler et al. 2012). This anti-inflammatory effect was also observed in healthy trained rats based on a decrease in two different anti-inflammatory markers (Barcelos et al. 2014). As a chemopreventive and anti-inflammatory agent, caffeine also acts as protective agent against cirrhosis and hepatic fibrosis, two chronic inflammatory diseases that can lead to liver cancer development. Thus, in a cirrhotic rat model, caffeine attenuates periportal inflammation and the level of inflammatory cells (Shim et al. 2013). This protective effect against hepatic fibrosis was confirmed on human drinking two cups of coffee per day over a 6-month period (Modi et al. 2010). By comparing the effect of a regular coffee and a similar coffee rich in melanoidins on the NF$\kappa \mathrm{B}$ pathway activity, Chu et al. (2013) highlighted the antiinflammatory properties of these complex compounds. Similar results were obtained with melanoidins generated during the $\mathrm{CO}_{2}$-decaffeination process (Chen et al. 2011).

\section{Cell proliferation inhibitors}

Elevated cell proliferation rates that characterize cancer are acquired via the deregulated production of growth factors, but can also be caused by an erroneous integration and interpretation of the induced signal. One of the main causes behind the out-of-control growth of tumor cells is an overproduction and elevated concentration of growth factors, such as hepatocyte growth factor (HGF) or VEGF, which are secreted by surrounding cells (paracrine signaling) as well as cancer cells themselves (autocrine signaling). The cancer cells can also overexpress or selfactivate receptors, such as human epidermal growth factor receptor (HER) or epidermal growth factor receptor (EGFR), and utilize mutations and alterations in receptor signaling pathways [e.g., Wnt, phosphoinositide 3-kinase (PI3K)-Akt pathways] that regulate cell growth (Hanahan and Weinberg 2011; Witsch et al. 2010).

As an anti-proliferative agent, kahweol (Fig. 1) decreases VEGF mRNA expression and protein expression in human breast cancer cells (MDA-MB-231) without affecting healthy cells (MCF-10A) (Kim et al. 2012). It also affects the proliferation of HN22 and HSC4 oral squamous cell lines by directly decreasing the level of the Sp1 (specificity protein 1) transcription factor (Chae et al. 2014).

Caffeine and caffeic acid (Fig. 1) inhibit the proliferation of two different breast cancer cell lines (MCF-7 and MDA-MB-231) by modulating the level of estrogen receptors (ER). Moreover, caffeine reduces the expression of the mitogenic insulin-like growth factor type I receptor (IGF-IR) in the same models (Rosendahl et al. 2014). Caffeine alone was also reported to decrease the human fibroblast growth factor 19 (FGF 19) mRNA level in the colorectal adenocarcinoma cell line LS174T and repress the expression of VEGF and EGFR in a dose-dependent manner in HeLa cells (Lu et al. 2014; Styer et al. 2014).

\section{Cell cycle progression inhibitors}

Growth factors are not the only agents involved in cellular proliferation. Indeed, this essential mechanism that ensures the homeostasis of an organism is also negatively regulated by other factors, such as tumor suppressor genes and proteins involved in cell cycle progression. Tumor suppressor genes, such as retinoblastoma ( $\mathrm{Rb})$, p53, adenomatous polyposis coli (APC) or phosphatase and tensin homolog (PTEN), act as sensors of cellular and genomic integrity and prevent cell cycle progression if necessary, whereas cyclins and cyclin-dependent kinases (cdks) are the key molecules of cell cycle progression that act by regulating the passage from one phase to the next phase of the cell cycle. Mutations or deregulations that affect tumor suppressor genes, cyclins, cdks or any related pathways that regulate cell cycle progression are regularly observed in cancer cells and held liable for their anarchic proliferation (Diaz-Moralli et al. 2013; Hanahan and Weinberg 2011).

In RT-2 malignant glioma cells, caffeine (Fig. 1) induces cell cycle arrest by increasing the level of phospho-eIF2a (eukaryotic translation initiation factor-2a), which decreases the level of cyclin D1 and leads to secondary cancer cell death via caspase-dependent and caspase-independent cell death pathways (Chen et al. 2014a). Similar 
results showing cell death by apoptosis after caffeine-induced cell cycle arrests were also observed in HeLa cells (Saiki et al. 2011).

5-Hydroxymethylfurfural (Fig. 1), a compound generated during the roasting process, indirectly results in cell cycle arrest in G0/G1 by inducing ROS generation and DNA damage and activating p53 as well as the Akt and MAPK pathways. This process leads to cell death by apoptosis after caspase cleavage (Zhao et al. 2014).

Oleaga et al. (2012) used microarray data and subsequent western blot analysis to confirm that caffeic acid (Fig. 1) decreases the level of cyclin D1 in MCF-7 breast and HT-29 colon cancer cell lines by modulating STAT-5B and activating transcription factor-2 (ATF-2). Caffeic acid and caffeine also reportedly arrest cells in the G1/S phase of the cell cycle in two breast cancer models (Rosendahl et al. 2014).

Two other small phenolic compounds found in coffee, ferulic acid and p-coumaric acid (Fig. 1) delay cell cycle progression. Although structurally very similar, they act differently in human Caco-2 epithelial colorectal adenocarcinoma cells; ferulic acid up-regulates genes involved in centrosome assembly, such as RABGAP1 (RAB GTPaseactivating protein 1) and CEP2 (Cdc42 effector protein 2) or genes responsible for the $\mathrm{S}$ phase checkpoint, such as SMC1L1 (structural maintenance of chromosomes protein 1A). $p$-coumaric acid up-regulates CDKN1A (cyclin-dependent kinase inhibitor 1), CCNA2 (cyclin A2) and CCNB1 (cyclin B1) (Janicke et al. 2011). In an in vivo inducible hamster buccal pouch carcinoma model, the oral administration of ferulic acid prevented cancer formation and down-regulated the expression of PCNA (proliferating cell nuclear antigen) and cyclin D1 (Prabhakar et al. 2012). After inducing cell cycle arrest in the G0/G1 phase, chlorogenic acid (Fig. 1) also reportedly triggered cell death via apoptosis in human acute promyelocytic leukemia HL-60 cells (Liu et al. 2013).

The heterogeneous melanoidins reduce proliferation and induce cell cycle arrest in G0 in the colon cancer cell line LS180 by affecting several key cell cycle regulators including cyclin D1, the cdk4, cdk6, p21, p27, p53 and $\mathrm{pRb}$. However, melanoidins act differently in C6 glioma cells; they induce cell cycle arrest in the G1/S phase by increasing p21 levels and decreasing the level of cyclin D1 (Langner et al. 2011, 2013).

\section{Aberrant metabolism modulators}

The exacerbated metabolic activity required for growth and proliferation rates beyond those of healthy cells requires the cancer cell to reorganize and increase its metabolic capacity. To this end, cancer cells require a more consistent supply of nutrients and oxygen via the formation of new blood vessels by angiogenesis (see "Angiogenesis inhibitors" section) and the up-regulation of the expression of glucose transporters and glycolytic enzymes. The cancer cell also adapts its canonical glucose metabolism and specifically complements the latter with the glutamine and lipid metabolisms. PPARs (peroxisome proliferator-activated receptors) are a family of nuclear receptors that regulate the expression of genes involved in glucose and lipid metabolism as well as genes involved in inflammation, immunity, angiogenesis, proliferation, migration and apoptosis. A recent analysis showed that they are one of the most promising targets for the development of drugs to fight metabolic diseases including diabetes, chronic inflammation and cancer (Hanahan and Weinberg 2011; Peters et al. 2012; Ward and Thompson 2012).

In a recent study, Aoyagi et al. analyzed the effect of coffee on the differentiation of mouse pre-adipocytes and the expression of PPAR $\gamma$-target genes involved in glucose metabolism. Their results show that both green and roasted coffee extracts inhibit the expression of PPAR $\gamma$, although the roasted extract was more efficient, which suggested that one or several compounds produced by roasting exert an inhibitory effect. A separate analysis excluded the role of caffeine, chlorogenic acids, caffeic acid and trigonelline in the negative modulation of PPAR $\gamma$ gene expression (Aoyagi et al. 2014). In this context, a previous study had already described hydroxyhydroquinone (Fig. 1), a compound found in roasted beans, as a repressor of the expression of glycolytic enzymes phosphoglycerate kinase 1 (PGK1) and pyruvate kinase M2 (PKM2) via PPAR $\gamma$ (Shashni et al. 2013).

Caffeine (Fig. 1) decreases the mRNA level of FGF 19 (fibroblast growth factor 19), a growth factor known to modulate genes involved in glucose uptake and metabolism (Styer et al. 2014). Caffeine and other methylxanthines including theophylline have also been reported as noncompetitive glucose transporter 1 (GLUT1) inhibitors, a transporter protein that is regularly overexpressed in cancer cells (Ojeda et al. 2012).

Two different decaffeinated green coffee bean extracts enriched in chlorogenic acid (Fig. 1) reportedly decrease the postprandial blood glucose level in healthy rat and human models. Deeper investigations revealed that chlorogenic acids, mainly caffeoylquinic acids and dicaffeoylquinic acids (Fig. 1), competitively inhibit the activity of glucose-6-phosphatase (G6Pase), the glycolytic enzyme responsible for the hydrolysis of glucose-6-phosphate (G6P) (Henry-Vitrac et al. 2010; Iwai et al. 2012). Chlorogenic acid and caffeic acid (Fig. 1) were shown to significantly decrease the body weight of mice fed with a high-fat diet. Both compounds significantly inhibited the activities of enzymes involved in lipid metabolism, such as fatty acid synthase, 3-hydroxy-3-methylglutaryl CoA 
reductase and acyl-CoA/cholesterol acyltransferase, while they increased the expression of PPAR $\alpha$. The authors noticed that chlorogenic acid was a more potent lipid metabolism inhibitor than caffeic acid (Cho et al. 2010).

\section{Angiogenesis inhibitors}

Because of its high metabolic rate, the tumor needs a constant supply of oxygen and nutrients and should also ensure the elimination of metabolic waste. Therefore, the formation of a dense network of blood vessels is an essential step in the tumor's development and spread. This process, which is quiescently and transiently reactivated in healthy tissues during wound healing, is regulated by the pressure of a complex balance between angiogenic activators, such as vascular endothelial growth factor (VEGF) and TNF- $\alpha$, and angiogenic inhibitors, such as thrombospondin, tissue inhibitor of metalloproteinase (TIMP). This process is also assisted by various types of healthy cells within the tumor microenvironment and cancer cells (Hanahan and Weinberg 2011; Welti et al. 2013).

Kahweol (Fig. 1), which is present at low concentrations in filtered coffee, is an anti-angiogenic polyvalent compound. A concentration of $10 \mathrm{nM}$ is sufficient to inhibit in vivo angiogenesis in a chicken chorioallantoic membrane (CAM) assay, and $75 \mu \mathrm{M}$ is sufficient in a zebrafish model. An ex vivo mouse aortic ring assay confirmed previous results, which showed that $25 \mu \mathrm{M}$ of kahweol completely inhibits angiogenesis. Moreover, kahweol inhibits the proliferation of proliferative and nonproliferative HUVEC cells at doses of approximately 50 and $150 \mu \mathrm{M}$, respectively. It also prevents the tubule formation of endothelial cells and their invasion in a Matrigel assay starting at a concentration of $25 \mu \mathrm{M}$ (Cardenas et al. 2011). In the same cells, kahweol dose-dependently decreases the IL-6-induced mRNA and protein expression levels of VEGF as well as the IL-6 induced migration and tubule formation after treatment with a minimal concentration of $1 \mu \mathrm{M}$ (Kim et al. 2012).

Cafestol (Fig. 1), a diterpene homologous to kahweol, also inhibits HUVEC proliferation and migration in a dosedependent manner at concentrations as low as $20 \mu \mathrm{M}$. At the same concentration, the mechanistic analysis shows that it partially or completely inhibits the phosphorylation of VEGFR2, Akt and focal adhesion kinase (FAK), but does not affect Erk 1/2, although a concentration of $5 \mu \mathrm{M}$ was sufficient to significantly decrease the tube formation in a Matrigel assay (Wang et al. 2012).

Caffeine (Fig. 1) exerts in vivo anti-angiogenic activity, as revealed by assays on chicken chorioallantoic membrane (CAM) and zebrafish embryos. Deeper investigations on human cells showed that caffeine inhibits the proliferation of HUVEC cells and induces their apoptosis by modulating caspase-3 and Bcl-2 (Li et al. 2013; Yeh et al. 2012).

Chlorogenic acid (Fig. 1) reportedly inhibited laser-induced choroidal neovascularization $(\mathrm{CNV})$ in a rat model (Kim et al. 2010). p-coumaric acid (Fig. 1), a phenolic constituent of chlorogenic acid that is released during its catabolism, inhibits the sprouting of endothelial cells in rat aortic rings and blocks the tube formation and migration of endothelial cells. It also decreases the secretion of growth factors (FGF, VEGF) at the mRNA level by acting on the Akt and Erk pathways (Kong et al. 2013).

\section{Invasion and metastasis inhibitors}

Like any living entity, cancer has a natural tendency to expand and spread to colonize cancer subtype-specific host organism niches. The hallmarks of metastasis and angiogenesis usually occur in advanced stages of the disease and require epithelial-mesenchymal transition (EMT). While cancer cells are initially anchored by adherence molecules, the influence of several activators, repressors and matrix metalloproteinases (MMPs) in the absence of TIMPs triggers the down-regulation or the loss of these molecules and allows the cancer cell to detach. After remodeling of the cytoskeleton, the cancer cell then moves and migrates through the body via blood and lymphatic vessels to healthy tissues and forms a metastasis (Hanahan and Weinberg 2011; Palmer et al. 2011).

Caffeine (Fig. 1) regulates the epithelial-mesenchymal transition and decreases the mRNA and protein levels of MMP-2 and MMP-9. In U937 cells, it increases the intracellular level of $\mathrm{Ca}^{2+}$ and ROS, inactivates extracellularsignal-regulated kinase (ERK) and activates p38 mitogenactivated protein kinase (MAPK) (Liu and Chang 2010; Lu et al. 2014). Caffeine was also reported to inhibit the migration of rat and human glioma cells and down-regulate the expression of phosphorylated $(p)$-FAK and $p$-paxillin, two proteins involved in the formation of focal adhesions (Chen et al. 2014b).

In agreement with its anti-angiogenic properties, kahweol (Fig. 1) $(25 \mu \mathrm{M})$ reduces the expression of MMP-2 and completely inhibits this enzyme and the protease urokinase $(50 \mu \mathrm{M})$ (Cardenas et al. 2011). At a lower concentration $(5 \mu \mathrm{M})$, it inhibits the migration and invasion of several human cancer cells lines, such as MDA-MB-231 (breast), A549 (lung) and PC3 (prostate). Under the same conditions, kahweol decreases the expression levels and activities of MMP-2 and MMP-9 in MDA-MB-231 cells via STAT-3 inactivation (Kim et al. 2012).

Chlorogenic and caffeic acid (Fig. 1), two phenolic compounds, suppress CT-26 cell-induced lung metastasis in a murine model. Chlorogenic acid reduces the activities of MMP-2 and MMP-9 and prevents the phosphorylation 
of ERK (mitogen-activated protein kinase). Moreover, caffeic acid inhibits the activities of MEK1 (dual specificity mitogen-activated protein kinase 1) and T-(lymphokine-activated killer) LAK cell-originated protein kinase (TOPK/PBK), which are known upstream activators of ERK, via non-competitive binding. These results, which demonstrated the inhibition of phospho-ERK, were confirmed in human samples by immunohistochemical analysis (Kang et al. 2011).

Melanoidins, which are nitrogen-containing products, are potent and selective inhibitors of the human zinc-containing endopeptidases MMP-1, MMP-2 and MMP-9, but are ineffective against ACE (angiotensin I-converting enzyme) and ChC (Clostridium histolyticum collagenase). This finding suggests that while melanoidins are known as zinc chelating agents, they specifically block the MMP active pocket (De Marco et al. 2011).

\section{Immortality}

To maintain homeostasis, healthy cells are limited to a defined number of growth-and-division cycles; this defined number is the Hayflick limit, which is estimated to 50 generations. The survival of cells depends on their ability to maintain telomeres, which are DNA sequences present at the ends of chromosomes and whose length decreases during each cycle of replication. To compensate for telomere erosion and achieve immortality, cancer cells activate telomerases, DNA polymerases responsible for the addition of a hexameric DNA sequence, or the alternative lengthening of telomeres (ALT) pathway, a telomeraseindependent mechanism, to maintain telomere integrity (Conomos et al. 2013; Hanahan and Weinberg 2011).

Chlorogenic acid (Fig. 1) acts on topoisomerases I and II that introduce transient single and double DNA strand breaks during DNA replication and chromatin remodeling. It induces the formation of topoisomerase I- and II-DNA complexes that arrest the cell until activation of apoptosis (Burgos-Moron et al. 2012). In an inducible oral tumor mouse model, ferulic acid (Fig. 1), a phenolic compound released during chlorogenic acid catabolism, decreased the expression of PCNA, an essential processivity factor of DNA replication (Prabhakar et al. 2012).

\section{Immune modulators}

Even though humans have evolved an effective innate and adaptive immune defense against a large number of diseases, pathogens and abnormal cells, this defense seems impotent toward cancer. On the contrary, immune cells present in the tumor microenvironment are deregulated and participate in cancer progression by secreting ROS, as well as pro-inflammatory, growth and angiogenic factors. This cellular reprogramming of immune cells, the difficulty to develop an antibody against self-antigens to specifically target cancer cells and ineffective or mutated antigen processing and presentation pathways, the loss of specific membrane markers and a resistance to cell death can mask the tumor from immune cell detection and protect against destruction (Hanahan and Weinberg 2011; Vesely et al. 2011).

An alcoholic extract or instant coffee powders prepared from Coffea arabica were reported to act as immunostimulants based on their ability to increase the level of total leukocytes in the blood of mice, induce the secretion of free radicals and IL- 2 by mouse immunocytes and activate B lymphocytes. After fractionation, the observed immunological activity was primarily attributed to different non-toxic arabinogalactan proteins and the polysaccharides arabinogalactans and galactomannans (Fig. 1) (Capek et al. 2014; Haque et al. 2013; Passos et al. 2014). An arabinogalactan protein composed of galactose and arabinose isolated from an instant coffee powder was shown to stimulate immunocompetent cells by inducing the release of IL-2, TNF- $\alpha$ and interferon (IFN)- $\gamma$ in ex vivo murine models (Nosál'ová et al. 2011).

\section{Cytotoxic agents}

One of the most recognized hallmarks of a cancer cell undoubtedly is its ability to resist apoptosis, a natural programmed cell death process that occurs in healthy cells to maintain homeostasis in the body. Apoptosis is triggered when the balance between pro-apoptotic (Bax, Bak...) and anti-apoptotic Bcl-2 family proteins [Bcl-2, Bcl-xL, myeloid cell leukemia (Mcl)-1] is disrupted. Two types of signals can initiate programmed cell death, intracellular signals including DNA damage or mitochondrial stress and extracellular signals by activation of death receptors by Fas ligand and TNF- $\alpha$ among others. The intrinsic and extrinsic pathways lead to the activation of initiator and executioner caspases responsible for the proteolysis of intracellular proteins and execution of apoptosis. While apoptosis is the best-known cell death mechanism, recent studies and observations have shown that a cell can die via various caspase-dependent and caspase-independent mechanisms. Moreover, controlled necrosis comprises by now an increasing number of cell demise modalities including parthanatos, oxytosis, ferroptosis, NETosis, pyronecrosis and pyroptosis, among other. Altogether cancer cells have developed several strategies to prevent the execution of cell death mechanisms, such as the inactivation of the p53 tumor suppressor gene, a DNA damage sensor, the overexpression of anti-apoptotic factors or the down-regulation of pro-apoptotic factors (Hanahan and Weinberg 2011; Ouyang et al. 2012). 
Two aqueous spent coffee extracts of $C$. arabica and robusta are reportedly cytotoxic to HeLa cells. Both treatments induce cell death in a dose-dependent manner after $24 \mathrm{~h}$ of treatment in a range of $37-3000 \mu \mathrm{g} / \mathrm{mL}$ $\left(\mathrm{IC}_{50} \pm 1000 \mu \mathrm{g} / \mathrm{mL}\right.$ ) (Bravo et al. 2013). The cytotoxic potential of the different coffee compounds has also been investigated in different cell models and in various conditions.

Thus, caffeine (Fig. 1) induced death of HeLa cells, and a western blot analysis showed the cleavage of PARP (poly ADP ribose polymerase) and caspase-3, prototypical markers of apoptosis. A flow cytometry analysis indicated dose-dependent increase in the sub-G1, S and G2/M populations and decrease in the G1 population after treatment. This alkaloid acts by down-regulating the mRNA levels of $\mathrm{p} 53 \alpha$ in favor of $\mathrm{p} 53 \beta$, leading to the down-regulation of SRSF3 (serine/arginine-rich splicing factor 3), a factor that regulates the expression of VEGF, EGFR, COX-2 and GLUT1 (Lu et al. 2014).

Cafestol (Fig. 1), one of the main diterpene alcohols, induces apoptosis in renal carcinoma Caki-1 cells by promoting the up-regulation of the pro-apoptotic proteins Bim and Bax and the down-regulation of the anti-apoptotic proteins cellular FLICE (FADD-like IL-1 $\beta$-converting enzyme) inhibitory protein (cFLIP), Bcl-2, Mcl-1, and Bcl$\mathrm{xL}$ via the inhibition of the Akt pathway (Choi et al. 2011). With kahweol (Fig. 1), these proteins can both trigger the apoptosis of human malignant pleural mesothelioma cells by decreasing protein and mRNA levels of the transcription factor Sp1. Although structurally similar, cafestol most effectively cleaved Bid, caspase-3 and PARP, whereas kahweol induced apoptosis by up-regulating Bax and down-regulating Bcl-xL (Lee et al. 2012).

In acute myelogenous leukemia (AML) U937 cells, chlorogenic acid (Fig. 1) induces ROS generation, reduces the mitochondrial membrane potential and activates caspase cleavage, which leads to apoptosis via caspase- and mitochondria-dependent pathways (Yang et al. 2012). Chlorogenic acid has also been reported as a cytotoxic agent; it induced cell death by apoptosis after cell cycle arrest in the human acute promyelocytic leukemia cell line HL-60 (Liu et al. 2013).

\section{Epidemiological studies and bioavailability}

Coffee consumption was sometimes considered a bad habit, and an excessive intake can induce side effects, notably due to caffeine, such as increased blood pressure, nausea or heart diseases (Cano-Marquina et al. 2013). Thus, coffee consumption is not recommended or at a reduced dose to children, pregnant women or patients with cardiovascular conditions. Recently, however, coffee consumption, more precisely the stimulatory molecule caffeine, was demonstrated to prevent depression and memory dysfunction caused by chronic stress in a rodent model (Kaster et al. 2015). Coffee consumption is also regularly associated with several health problems, such as heart disease and cancer development. Recently, an important study associated esophageal cancer development with the consumption of overheated beverages, such as tea, and not directly with the molecular components of coffee (Islami et al. 2009). Worldwide consumption of coffee products clearly demonstrates its non-toxicity. It is nevertheless important to know that caffeine becomes lethal at very high doses (150-200 mg/kg (http://toxnet.nlm.nih. gov. Accessed October 2015) corresponding to 11.25-15 g for a $75 \mathrm{~kg}$ adult, $>65,125-\mathrm{mL}$ cups of brewed coffee (based on a concentration of $1.39 \mathrm{mg}$ of caffeine/mL) corresponding to $8 \mathrm{~L}$. This extreme value has to be compared to the amounts used in cohort studies that highlighted the chemopreventive effect of coffee on several types of cancer taken over a few days to several decades. Overall, most studies have demonstrated that an average consumption of 4-6 cups of coffee per day, which corresponds to a total consumption of $750 \mathrm{~mL}$, is sufficient to prevent carcinogenesis and slow the progression of different types of cancer ( $\mathrm{Yu}$ et al. 2011). This recommendation is in line with other studies that attest that $400 \mathrm{mg}$ of caffeine per day, which is roughly the amount of caffeine contained in 4-6 cups, is safe for adults (Mejia and Ramirez-Mares 2014). Interestingly, the consumption of $750 \mathrm{~mL}$ of black coffee per day $(3 \times 250 \mathrm{~mL})$ has been shown to beneficially affect health after 4 weeks by contributing to the maintenance of DNA integrity and by significantly decreasing the expression of genes involved in the inflammation process (Nrf2, IL-6, PPAR $\alpha$ and PPAR $\gamma$ ) (Bakuradze et al. 2014; Winkler et al. 2014).

The consumption of caffeinated coffee is more common than that of decaffeinated coffee; thus, data that demonstrate that the consumption of a special type of coffee confers an advantage are lacking, even though caffeine exerts anticancer activities, as discussed in this review. By comparing the effects of regular coffee consumption and decaffeinated coffee consumption, several clinical studies revealed that caffeinated coffee drinkers are at a lower risk of developing cancer, unlike decaffeinated coffee consumers (Ferrucci et al. 2014; Giri et al. 2011; Hildebrand et al. 2013).

Numerous clinical studies and multiple additional studied have confirmed that the daily consumption of several cups of coffee prevents and fights cancer. This finding demonstrates that coffee contains anticancer compounds that are naturally present at a therapeutic concentration. In-depth analyses have revealed the presence of several dozens of different molecules in a single cup of 


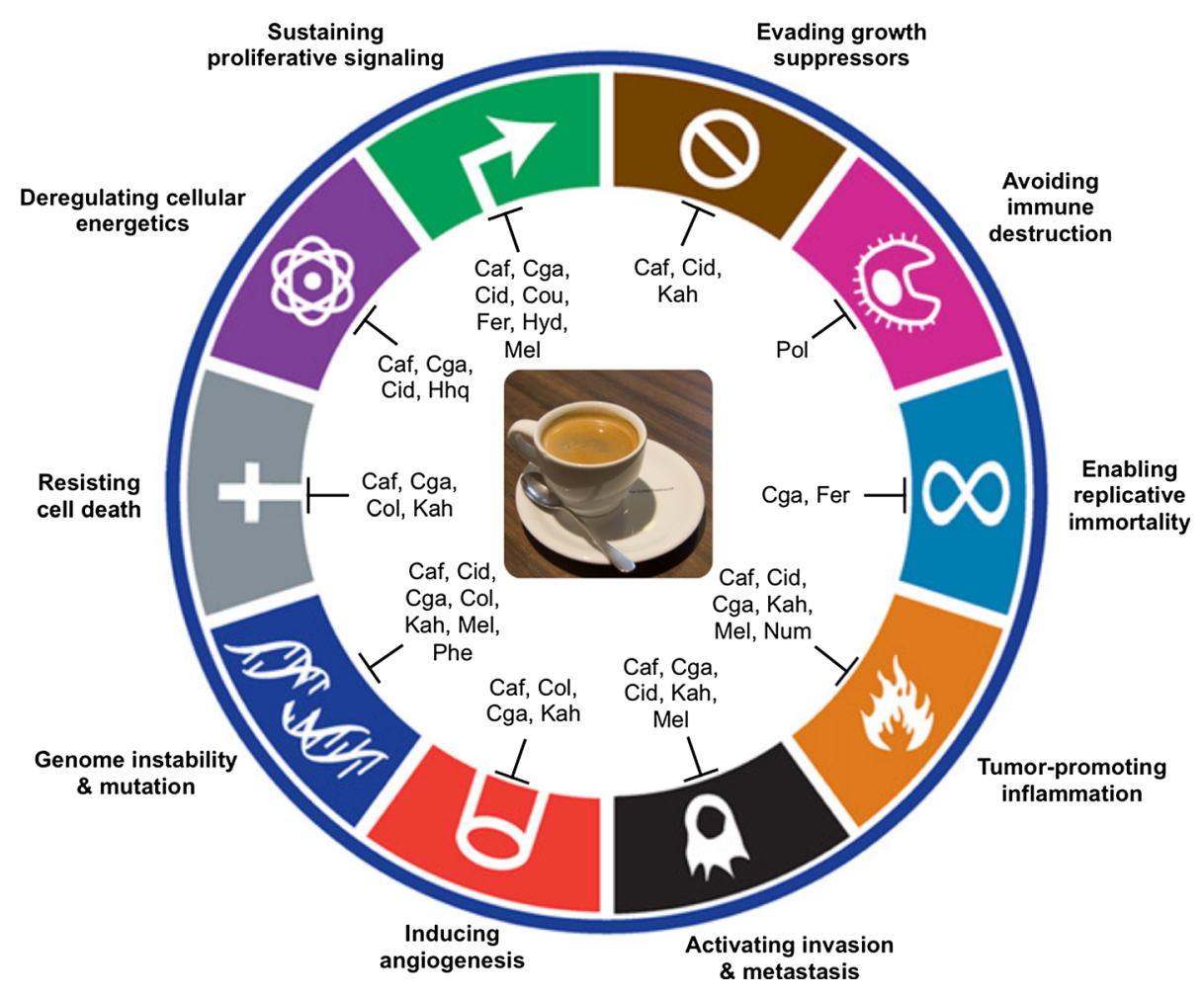

Fig. 3 Natural compounds from coffee targeting the hallmarks of cancer, based on Hanahan and Weinberg (2011), with modifications. This figure adapted from (Hanahan and Weinberg 2011) summarizes the anticancer effects of all molecules presented in this review. A non-exhaustive recent bibliography includes (Ambothi and Nagarajan 2014; Baeza et al. 2014; Bravo et al. 2013; Burgos-Moron et al. 2012; Capek et al. 2014; Caporaso et al. 2014; Chen et al. 2014a; Haque

coffee that could be described as a coffeome based on the abundance and diversity of molecules (Ludwig et al. 2013b; Rodrigues and Bragagnolo 2013). In fact, this complexity is amplified once the coffee is drunk; the gut microbiome and human enzymes catalyze and modify the coffeome to release yet new compounds with unique activities.

Because of their abundance, structural heterogeneity or biological activity, caffeine and chlorogenic acids are the compounds whose bioavailability (amount of absorbed substance available for physiological functions), bio-accessibility (amount of absorbed substance available for assimilation in the gut after digestion) and catabolism after coffee ingestion (Mills et al. 2013; Mullen et al. 2011) are mainly being studied.

The consumption of $400 \mathrm{~mL}$ of coffee leads to the release of at least 34 coffee metabolites ( 22 phenolic acid derivatives and 12 chlorogenic acids derivatives) in human plasma. These compounds mainly consist of glucuronidated and sulfonated forms of caffeic acid, coumaric acid, caffeoylquinic acid and more complex compounds, such as dihydro-isoferulic acid-3-O-glucuronide or (dihydro)coumaric acid $O$-sulfates (Crozier et al. 2010; Redeuil et al. 2013; Passos et al. 2014; Rodrigues et al. 2013; Vicente et al. 2014). Caf caffeine, Col cafestol, Cid caffeic acid, Cga chlorogenic acids, Cou p-coumaric acid, Fer ferulic acid, Hhq hydroxyhydroquinone, Hyd 5-hydroxymethylfurfural, Kah kahweol, Mel melanoidins, Num N-methylpyridinium, Phe phenolic compounds, Pol polysaccharides

et al. 2011). Ludwig et al. incubated freshly prepared coffee with human colonic microflora at $37{ }^{\circ} \mathrm{C}$ to specifically analyze the effect of the human colonic microbiota and discovered that the pool of 20 chlorogenic acids initially present in coffee shifts to 11 catabolites after $6 \mathrm{~h}$. However, this decrease in the number of compounds should be qualified by the fact that many molecules are isomers of the initial chlorogenic acids (Ludwig et al. 2013b).

The metabolism of the molecules originally contained in coffee and the appearance of novel catabolites allows new biological properties to emerge that were initially absent in coffee at the time of consumption. In a comparative study, the anti-radical activity of a raw coffee extract increased; the $\mathrm{EC}_{50}$ value decreased from 1.86 to $1.47 \mathrm{mg} / \mathrm{mL}$ after in vitro digestion. Lipoxygenase (LOX), an enzyme responsible for the generation of ROS and involved in the inflammation process, was similarly inhibited; the $\mathrm{IC}_{50}$ decreased from 4.22 to $1.45 \mathrm{mg} / \mathrm{mL}$ after simulated gastrointestinal digestion (Durak et al. 2014). Similarly, the products obtained from a simulated gastrointestinal digestion of melanoidins from coffee exerted a higher hydroxyl radical scavenging activity and more efficiently protected 
DNA than non-digested melanoidins. This effect could be explained by the release of free phenolic compounds from melanoidins during the digestion process (Del Pino-Garcia et al. 2012).

\section{Conclusion}

Coffee is one of the most widely consumed beverages in the world due notably to its low cost and ease of preparation. As underlined in our review, coffee is also clearly one of the most chemically complex natural drinks, and a cup of regular dark coffee contains abundant heterogeneous bioactive compounds which are naturally present in coffee but which are also generated during the production process and also after ingestion during catabolism by the human microbiota (Figs. 1, 2). Many of these molecules act on the different hallmarks and enabling characteristics of cancer and thus help to prevent the appearance and development of this disease (Fig. 3), which have been confirmed by numerous studies that have highlighted that a daily consumption of $750 \mathrm{~mL}$ of regular dark coffee helps to protect and prevent cancer progression.

Nevertheless, it goes without saying that coffee consumption alone cannot be considered as the perfect natural chemopreventive and chemotherapeutic medicine, but must be with good reason included into a healthy lifestyle which only it can contribute to prevent cancer development and progression.

Acknowledgments F.G. was supported by a grant from ITN "RedCat" 215009. Research at LBMCC is financially supported by the Fondation de Recherche Cancer et Sang, the Recherches Scientifiques Luxembourg association, the Een Haerz fir kriibskrank Kanner association, the Action Lions Vaincre le Cancer association, the European Union (ITN "RedCat" 215009, Interreg IVa Project "Corena") and the Télévie Luxembourg. MD is supported by the National Research Foundation (NRF) by the MEST of Korea for Tumor Microenvironment Global Core Research Center (GCRC) Grant (Grant No. 2012-0001184) and by Brain Korea BK21. The authors thank the coffee shop "Golden Bean" (23, Rue Chimay L-1333 Luxembourg, Grand Duchy of Luxembourg) for kindly providing material (coffee beans and coffees) for the creation of figures.

\section{References}

Afify AE-MM, Shalaby EA, El-Beltagi HS (2011) Antioxidant activity of aqueous extracts of different caffeine products. Not Bot Horti Agrobot Cluj-Napoca 39:117-123

Alao JP, Sunnerhagen P (2009) The ATM and ATR inhibitors CGK733 and caffeine suppress cyclin D1 levels and inhibit cell proliferation. Radiat Oncol 4:51. doi:10.1186/1748-717X-4-51

Ambothi K, Nagarajan RP (2014) Ferulic acid prevents ultraviolet-B radiation induced oxidative DNA damage in human dermal fibroblasts. Int J Nutr Pharmacol Neurol Dis 4:203
Andueza S, Manzocco L, Paz de Peña M, Cid C, Nicoli C (2009) Caffeic acid decomposition products: Antioxidants or prooxidants? Food Res Int 42:51-55

Aoyagi R, Funakoshi-Tago M, Fujiwara Y, Tamura H (2014) Coffee inhibits adipocyte differentiation via inactivation of PPAR $\gamma$. Biol Pharm Bull 37:1820-1825. doi:10.1248/bpb.b14-00378

Bacanlı M, Taner G, Göktaş HG, Şahin T, Başaran AA, Başaran N (2014) The protective role of ferulic acid on sepsis-induced oxidative damage in Wistar albino rats. Environ Toxicol Pharmacol 38:774-782

Baeza G, Amigo-Benavent M, Sarriá B, Goya L, Mateos R, Bravo L (2014) Green coffee hydroxycinnamic acids but not caffeine protect human HepG2 cells against oxidative stress. Food Res Int 62:1038-1046

Bakuradze T et al (2014) Four weeks coffee consumption affects energy intake, satiety regulation, body fat, and protects DNA integrity. Food Res Int 63:420-427. doi:10.1016/j.foodres.2014. 05.032

Bakuradze T, Lang R, Hofmann T, Eisenbrand G, Schipp D, Galan J, Richling E (2015) Consumption of a dark roast coffee decreases the level of spontaneous DNA strand breaks: a randomized controlled trial. Eur J Nutr 54:149-156. doi:10.1007/s00394014-0696-x

Barcelos RP et al (2014) Caffeine intake may modulate inflammation markers in trained rats. Nutrients 6:1678-1690

Belviso S et al (2014) Phytochemical and microbiological stability of spent espresso coffee grounds in capsules. Food Res Int 61:93-99. doi:10.1016/j.foodres.2014.02.035

Bessler H, Salman H, Bergman M, Djaldetti M (2012) Caffeine alters cytokine secretion by PBMC induced by colon cancer cells. Cancer Investig 30:87-91

Bichler J et al (2007) Coffee consumption protects human lymphocytes against oxidative and 3-amino-1-methyl-5H-pyrido[4,3b]indole acetate (Trp-P-2) induced DNA-damage: results of an experimental study with human volunteers. Food Chem Toxicol 45:1428-1436. doi:10.1016/j.fct.2007.02.001

Boettler U et al (2011) Coffees rich in chlorogenic acid or $\mathrm{N}$ methylpyridinium induce chemopreventive phase II-enzymes via the Nrf2/ARE pathway in vitro and in vivo. Mol Nutr Food Res 55:798-802. doi:10.1002/mnfr.201100115

Bond TJ (2011) The origins of tea, coffee and cocoa as beverages. In: Tea, cocoa and coffee: plant secondary metabolites and health. Wiley-Blackwell Publishing, Oxford, pp 1-24. doi:10.1002/ 9781444347098.ch1

Bravo J, Arbillaga L, de Pena MP, Cid C (2013) Antioxidant and genoprotective effects of spent coffee extracts in human cells. Food Chem Toxicol 60:397-403. doi:10.1016/j.fct.2013.08.002

Bufalo MC et al (2013) Propolis and its constituent caffeic acid suppress LPS-stimulated pro-inflammatory response by blocking NF-kappaB and MAPK activation in macrophages. J Ethnopharmacol 149:84-92. doi:10.1016/j.jep.2013.06.004

Burgos-Moron E et al (2012) The coffee constituent chlorogenic acid induces cellular DNA damage and formation of topoisomerase I- and II-DNA complexes in cells. J Agric Food Chem 60:7384-7391. doi:10.1021/jf300999e

Cano-Marquina A, Tarin JJ, Cano A (2013) The impact of coffee on health. Maturitas 75:7-21. doi:10.1016/j.maturitas.2013.02.002

Capek P, Paulovicova E, Matulova M, Mislovicova D, Navarini L, Suggi-Liverani F (2014) Coffea arabica instant coffee-chemical view and immunomodulating properties. Carbohydr Polym 103:418-426. doi:10.1016/j.carbpol.2013.12.068

Caporaso N, Genovese A, Canela MD, Civitella A, Sacchi R (2014) Neapolitan coffee brew chemical analysis in comparison to espresso, moka and American brews. Food Res Int 61:152-160. doi:10.1016/j.foodres.2014.01.020 
Cardenas C, Quesada AR, Medina MA (2011) Anti-angiogenic and anti-inflammatory properties of kahweol, a coffee diterpene. PLoS One 6:e23407. doi:10.1371/journal.pone.0023407

Cerella C, Teiten MH, Radogna F, Dicato M, Diederich M (2014) From nature to bedside: pro-survival and cell death mechanisms as therapeutic targets in cancer treatment. Biotechnol Adv 32:1111-1122. doi:10.1016/j.biotechadv.2014.03.006

Chae JI, Jeon YJ, Shim JH (2014) Anti-proliferative properties of kahweol in oral squamous cancer through the regulation specificity protein 1 . Phytother Res 28:1879-1886

Chen Y, Brown PH, Hu K, Black RM, Prior RL, Ou B, Chu YF (2011) Supercritical $\mathrm{CO}_{2}$ decaffeination of unroasted coffee beans produces melanoidins with distinct $\mathrm{NF}-\kappa \mathrm{B}$ inhibitory activity. J Food Sci 76:H182-H186

Chen J-C, Hwang J-H, Chiu W-H, Chan Y-C (2014a) Tetrandrine and caffeine modulated cell cycle and increased glioma cell death via caspase-dependent and caspase-independent apoptosis pathways. Nutr Cancer 66:700-706

Chen Y, Chou W-C, Ding Y-M, Wu Y-C (2014b) Caffeine inhibits migration in glioma cells through the ROCK-FAK pathway. Cell Physiol Biochem 33:1888-1898

Cheong MW, Tong KH, Ong JJM, Liu SQ, Curran P, Yu B (2013) Volatile composition and antioxidant capacity of Arabica coffee. Food Res Int 51:388-396

Cho A-S, Jeon S-M, Kim M-J, Yeo J, Seo K-I, Choi M-S, Lee M-K (2010) Chlorogenic acid exhibits anti-obesity property and improves lipid metabolism in high-fat diet-induced-obese mice. Food Chem Toxicol 48:937-943

Choi MJ et al (2011) Cafestol, a coffee-specific diterpene, induces apoptosis in renal carcinoma Caki cells through down-regulation of anti-apoptotic proteins and Akt phosphorylation. Chem Biol Interact 190:102-108

Chu YF, Hu K, Hatzold T, Black RM, Chen D (2013) Flaking process increases the NF- $\mathrm{\kappa B}$ inhibition activity and melanoidin extractability of coffee. Food Sci Nutr 1:363-368

Conomos D, Pickett HA, Reddel RR (2013) Alternative lengthening of telomeres: remodeling the telomere architecture. Front Oncol 3:27. doi: $10.3389 /$ fonc. 2013.00027

Crozier A, Del Rio D, Clifford MN (2010) Bioavailability of dietary flavonoids and phenolic compounds. Mol Asp Med 31:446-467. doi:10.1016/j.mam.2010.09.007

De Marco LM, Fischer S, Henle T (2011) High molecular weight coffee melanoidins are inhibitors for matrix metalloproteases. J Agric Food Chem 59:11417-11423. doi:10.1021/jf202778w

de Mejia EG, Ramirez-Mares MV (2014) Impact of caffeine and coffee on our health. Trends Endocrinol Metab 25:489-492. doi:10.1016/j.tem.2014.07.003

Del Pino-Garcia R, Gonzalez-SanJose ML, Rivero-Perez MD, Muniz $P$ (2012) Influence of the degree of roasting on the antioxidant capacity and genoprotective effect of instant coffee: contribution of the melanoidin fraction. J Agric Food Chem 60:10530-10539. doi:10.1021/jf302747v

Diaz-Moralli S, Tarrado-Castellarnau M, Miranda A, Cascante M (2013) Targeting cell cycle regulation in cancer therapy. Pharmacol Ther 138:255-271. doi:10.1016/j.pharmthera.2013.01.011

Duarte GS, Pereira AA, Farah A (2010) Chlorogenic acids and other relevant compounds in Brazilian coffees processed by semi-dry and wet post-harvesting methods. Food Chem 118:851-855. doi:10.1016/j.foodchem.2009.05.042

Durak A, Gawlik-Dziki U, Pecio L (2014) Coffee with cinnamonimpact of phytochemicals interactions on antioxidant and antiinflammatory in vitro activity. Food Chem 162:81-88. doi:10. 1016/j.foodchem.2014.03.132

Ebrahim W et al (2013) Embellicines A and B: absolute configuration and NF-kappaB transcriptional inhibitory activity. J Med Chem 56:2991-2999. doi:10.1021/jm400034b
Ferk F et al (2014) Protective effects of coffee against induction of DNA damage and pre-neoplastic foci by aflatoxin B1. Mol Nutr Food Res 58:229-238

Ferrucci LM, Cartmel B, Molinaro AM, Leffell DJ, Bale AE, Mayne ST (2014) Tea, coffee, and caffeine and early-onset basal cell carcinoma in a case-control study. Eur J Cancer Prev 23:296-302. doi:10.1097/CEJ.0000000000000037

Gaascht F, Teiten MH, Schumacher M, Dicato M, Diederich M (2010) Approche végétale dans le traitement des leucémies. Corresp Onco-hématologie V(2):102-108

Gaascht F, Teiten MH, Cerella C, Dicato M, Bagrel D, Diederich M (2014) Plumbagin modulates leukemia cell redox status. Molecules 19:10011-10032. doi:10.3390/molecules190710011

Giri A, Sturgeon SR, Luisi N, Bertone-Johnson E, Balasubramanian R, Reeves KW (2011) Caffeinated coffee, decaffeinated coffee and endometrial cancer risk: a prospective cohort study among US postmenopausal women. Nutrients 3:937-950

Grivennikov SI, Greten FR, Karin M (2010) Immunity, inflammation, and cancer. Cell 140:883-899. doi:10.1016/j.cell.2010.01.025

Hanahan D, Weinberg RA (2011) Hallmarks of cancer: the next generation. Cell 144:646-674. doi:10.1016/j.cell.2011.02.013

Haque MR, Ansari SH, Rashikh A (2013) Coffea arabica seed extract stimulate the cellular immune function and cyclophosphamideinduced immunosuppression in mice. Iran $\mathrm{J}$ Pharm Res 12:101-108

Hečimović I, Belščak-Cvitanović A, Horžić D, Komes D (2011) Comparative study of polyphenols and caffeine in different coffee varieties affected by the degree of roasting. Food Chem 129:991-1000. doi:10.1016/j.foodchem.2011.05.059

Heng HH, Stevens JB, Bremer SW, Liu G, Abdallah BY, Ye CJ (2011) Evolutionary mechanisms and diversity in cancer. Adv Cancer Res 112:217-253. doi:10.1016/B978-0-12-387688-1.00008-9

Henry-Vitrac C, Ibarra A, Roller M, Merillon JM, Vitrac X (2010) Contribution of chlorogenic acids to the inhibition of human hepatic glucose-6-phosphatase activity in vitro by Svetol, a standardized decaffeinated green coffee extract. J Agric Food Chem 58:4141-4144. doi:10.1021/jf9044827

Hildebrand JS, Patel AV, McCullough ML, Gaudet MM, Chen AY, Hayes RB, Gapstur SM (2013) Coffee, tea, and fatal oral/ pharyngeal cancer in a large prospective US cohort. Am J Epidemiol 177:50-58. doi:10.1093/aje/kws222

Huber WW, Scharf G, Nagel G, Prustomersky S, Schulte-Hermann R, Kaina B (2003) Coffee and its chemopreventive components kahweol and cafestol increase the activity of $O 6$-methylguanineDNA methyltransferase in rat liver-comparison with phase II xenobiotic metabolism. Mutat Res 522:57-68

Hwang SJ, Kim YW, Park Y, Lee HJ, Kim KW (2014) Antiinflammatory effects of chlorogenic acid in lipopolysaccharidestimulated RAW 264.7 cells. Inflamm Res 63:81-90. doi:10. 1007/s00011-013-0674-4

Islami F et al (2009) Tea drinking habits and oesophageal cancer in a high risk area in northern Iran: population based case-control study. BMJ 338:b929. doi:10.1136/bmj.b929

Iwai K, Narita Y, Fukunaga T, Nakagiri O, Kamiya T, Ikeguchi M, Kikuchi Y (2012) Study on the postprandial glucose responses to a chlorogenic acid-rich extract of decaffeinated green coffee beans in rats and healthy human subjects. Food Sci Technol Res 18:849-860. doi:10.3136/fstr.18.849

Janicke B, Hegardt C, Krogh M, Önning G, Åkesson B, Cirenajwis HM, Oredsson SM (2011) The antiproliferative effect of dietary fiber phenolic compounds ferulic acid and $p$-coumaric acid on the cell cycle of Caco-2 cells. Nutr Cancer 63:611-622. doi:10. 1080/01635581.2011.538486

Kang NJ et al (2011) Coffee phenolic phytochemicals suppress colon cancer metastasis by targeting MEK and TOPK. Carcinogenesis 32:921-928. doi:10.1093/carcin/bgr022 
Kaster MP et al (2015) Caffeine acts through neuronal adenosine A2A receptors to prevent mood and memory dysfunction triggered by chronic stress. Proc Natl Acad Sci USA 112:7833-7838. doi:10. 1073/pnas. 1423088112

Kim C, Yu HG, Sohn J (2010) The anti-angiogenic effect of chlorogenic acid on choroidal neovascularization. Korean $\mathrm{J}$ Ophthalmol 24:163-168. doi:10.3341/kjo.2010.24.3.163

Kim HG et al (2012) The coffee diterpene kahweol inhibits metastasis by modulating expressions of MMPs and VEGF via STAT3 inactivation. Food Chem 133:1521-1529. doi:10.1016/j.food chem.2012.02.043

Kitzberger CSG, Scholz MBdS, Benassi MdT (2014) Bioactive compounds content in roasted coffee from traditional and modern Coffea arabica cultivars grown under the same edapho-climatic conditions. Food Res Int 61:61-66. doi:10. 1016/j.foodres.2014.04.031

Kong CS, Jeong CH, Choi JS, Kim KJ, Jeong JW (2013) Antiangiogenic effects of $p$-coumaric acid in human endothelial. Cells Phytother Res 27:317-323. doi:10.1002/ptr.4718

Kwak SC et al (2013) Chlorogenic acid inhibits osteoclast differentiation and bone resorption by down-regulation of receptor activator of nuclear factor kappa-B ligand-induced nuclear factor of activated $\mathrm{T}$ cells $\mathrm{c} 1$ expression. Biol Pharm Bull 36:1779-1786. doi:10.1248/bpb.b13-00430

Langner E, Nunes FM, Pozarowski P, Kandefer-Szerszen M, Pierzynowski SG, Rzeski W (2011) Antiproliferative activity of melanoidins isolated from heated potato fiber (Potex) in glioma cell culture model. J Agric Food Chem 59:2708-2716. doi:10.1021/jf1047223

Langner E, Nunes FM, Pożarowski P, Kandefer-Szerszeń M, Pierzynowski SG, Rzeski W (2013) Melanoidins isolated from heated potato fiber (Potex) affect human colon cancer cells growth via modulation of cell cycle and proliferation regulatory proteins. Food Chem Toxicol 57:246-255. doi:10.1016/j.fct. 2013.03.042

Lee KJ, Jeong HG (2007) Protective effects of kahweol and cafestol against hydrogen peroxide-induced oxidative stress and DNA damage. Toxicol Lett 173:80-87. doi:10.1016/j.toxlet.2007.06. 008

Lee K-A, Chae J-I, Shim J-H (2012) Natural diterpenes from coffee, cafestol and kahweol induce apoptosis through regulation of specificity protein 1 expression in human malignant pleural mesothelioma. J Biomed Sci 19:1-10. doi:10.1186/1423-0127-1960

Lee JY, Orlikova B, Diederich M (2015) Signal transducers and activators of transcription (STAT) regulatory networks in marine organisms: from physiological observations towards marine. Drug Discov Mar Drugs 13:4967-4984. doi:10.3390/md13084967

Li H, Jin SY, Son HJ, Seo JH, Jeong GB (2013) Caffeine-induced endothelial cell death and the inhibition of angiogenesis. Anat Cell Biol 46:57-67. doi:10.5115/acb.2013.46.1.57

Liou GY, Storz P (2010) Reactive oxygen species in cancer. Free Radical Res 44:479-496. doi:10.3109/10715761003667554

Liu WH, Chang LS (2010) Caffeine induces matrix metalloproteinase-2 (MMP-2) and MMP-9 down-regulation in human leukemia U937 cells via $\mathrm{Ca}^{2+} / \mathrm{ROS}$-mediated suppression of ERK/c-fos pathway and activation of $\mathrm{p} 38 \mathrm{MAPK} / \mathrm{c}-\mathrm{jun}$ pathway. J Cell Physiol 224:775-785. doi:10.1002/jcp.22180

Liu YJ, Zhou CY, Qiu CH, Lu XM, Wang YT (2013) Chlorogenic acid induced apoptosis and inhibition of proliferation in human acute promyelocytic leukemia HL-60 cells. Mol Med Rep 8:1106-1110. doi:10.3892/mmr.2013.1652

Lu G-Y, Huang S-M, Liu S-T, Liu P-Y, Chou W-Y, Lin W-S (2014) Caffeine induces tumor cytotoxicity via the regulation of alternative splicing in subsets of cancer-associated genes. Int $\mathbf{J}$ Biochem Cell Biol 47:83-92. doi:10.1016/j.biocel.2013.12.004
Ludwig IA, Sanchez L, Caemmerer B, Kroh LW, De Peña MP, Cid C (2012) Extraction of coffee antioxidants: impact of brewing time and method. Food Res Int 48:57-64. doi:10.1016/j.foodres.2012. 02.023

Ludwig IA, Bravo J, De Peña MP, Cid C (2013a) Effect of sugar addition (torrefacto) during roasting process on antioxidant capacity and phenolics of coffee. LWT Food Sci Technol 51:553-559. doi:10.1016/j.lwt.2012.12.010

Ludwig IA, Paz de Pena M, Concepcion C, Alan C (2013b) Catabolism of coffee chlorogenic acids by human colonic microbiota. Biofactors 39:623-632. doi:10.1002/biof.1124

Majer BJ et al (2005) Coffee diterpenes prevent the genotoxic effects of 2-amino-1-methyl-6-phenylimidazo[4,5-b]pyridine (PhIP) and $N$-nitrosodimethylamine in a human derived liver cell line (HepG2). Food Chem Toxicol 43:433-441. doi:10.1016/j.fct. 2004.11.009

Malvezzi M, Bertuccio P, Rosso T, Rota M, Levi F, La Vecchia C, Negri E (2015) European cancer mortality predictions for the year 2015: Does lung cancer have the highest death rate in EU women? Ann Oncol 26:779-786. doi:10.1093/annonc/mdv001

Matulova M, Capek P, Kaneko S, Navarini L, Liverani FS (2011) Structure of arabinogalactan oligosaccharides derived from arabinogalactan-protein of Coffea arabica instant coffee powder. Carbohydr Res 346:1029-1036. doi:10.1016/j.carres.2011.03. 016

Maurya DK, Devasagayam TPA (2013) Ferulic acid inhibits gamma radiation-induced DNA strand breaks and enhances the survival of mice. Cancer Biother Radiopharm 28:51-57. doi:10.1089/cbr. 2012.1263

Merlo LM, Pepper JW, Reid BJ, Maley CC (2006) Cancer as an evolutionary and ecological process. Nat Rev Cancer 6:924-935. doi: $10.1038 / \mathrm{nrc} 2013$

Mestdagh F, Davidek T, Chaumonteuil M, Folmer B, Blank I (2014) The kinetics of coffee aroma extraction. Food Res Int 63:271-274. doi:10.1016/j.foodres.2014.03.011

Mills CE, Oruna-Concha MJ, Mottram DS, Gibson GR, Spencer JP (2013) The effect of processing on chlorogenic acid content of commercially available coffee. Food Chem 141:3335-3340. doi:10.1016/j.foodchem.2013.06.014

Modi AA, Feld JJ, Park Y, Kleiner DE, Everhart JE, Liang TJ, Hoofnagle JH (2010) Increased caffeine consumption is associated with reduced hepatic fibrosis. Hepatology 51:201-209. doi:10.1002/hep.23279

Morceau F, Chateauvieux S, Orsini M, Trecul A, Dicato M, Diederich M (2015) Natural compounds and pharmaceuticals reprogram leukemia cell differentiation pathways. Biotechnol Adv 33:785-797. doi:10.1016/j.biotechadv.2015.03.013

Moreira AS, Nunes FM, Domingues MR, Coimbra MA (2012) Coffee melanoidins: structures, mechanisms of formation and potential health impacts. Food Funct 3:903-915. doi:10.1039/c2fo30048f

Moreira MEC et al (2013) Anti-inflammatory effect of aqueous extracts of roasted and green Coffea arabica L. J Funct Foods 5:466-474

Mullen W, Nemzer B, Ou B, Stalmach A, Hunter J, Clifford MN, Combet E (2011) The antioxidant and chlorogenic acid profiles of whole coffee fruits are influenced by the extraction procedures. J Agric Food Chem 59:3754-3762. doi:10.1021/ jf200122m

Muller F, Cerella C, Radogna F, Dicato M, Diederich M (2015) Effects of natural products on Mcl-1 expression and function. Curr Med Chem 22(30):3447-3461

Negrini S, Gorgoulis VG, Halazonetis TD (2010) Genomic instability - an evolving hallmark of cancer Nature reviews. Mol Cell Biol 11:220-228. doi:10.1038/nrm2858

Niseteo T, Komes D, Belscak-Cvitanovic A, Horzic D, Budec M (2012) Bioactive composition and antioxidant potential of 
different commonly consumed coffee brews affected by their preparation technique and milk addition. Food Chem 134:1870-1877. doi:10.1016/j.foodchem.2012.03.095

Nosál'ová G, Prisenžňáková L, Paulovičová E, Capek P, Matulová M, Navarini L, Liverani FS (2011) Antitussive and immunomodulating activities of instant coffee arabinogalactan-protein. Int $\mathrm{J}$ Biol Macromol 49:493-497. doi:10.1016/j.ijbiomac.2011.06.004 Ojeda P et al (2012) Noncompetitive blocking of human GLUT1 hexose transporter by methylxanthines reveals an exofacial regulatory binding site. Am J Physiol Cell Physiol 303:C530 C539. doi:10.1152/ajpcell.00145.2012

Oleaga C, Noé V, Izquierdo-Pulido M (2012) Coffee polyphenols change the expression of STAT5B and ATF-2 modifying cyclin D1 levels in cancer cells. Oxid Med Cell Longev. doi:10.1155/ 2012/390385

Ouyang L, Shi Z, Zhao S, Wang FT, Zhou TT, Liu B, Bao JK (2012) Programmed cell death pathways in cancer: a review of apoptosis, autophagy and programmed necrosis. Cell Prolif 45:487-498. doi:10.1111/j.1365-2184.2012.00845.x

Palmer TD, Ashby WJ, Lewis JD, Zijlstra A (2011) Targeting tumor cell motility to prevent metastasis. Adv Drug Deliv Rev 63:568-581. doi:10.1016/j.addr.2011.04.008

Passos CP et al (2014) Influence of molecular weight on in vitro immunostimulatory properties of instant coffee. Food Chem 161:60-66. doi:10.1016/j.foodchem.2014.03.119

Perrone D, Farah A, Donangelo CM (2012) Influence of coffee roasting on the incorporation of phenolic compounds into melanoidins and their relationship with antioxidant activity of the brew. J Agric Food Chem 60:4265-4275. doi:10.1021/ jf205388x

Peters JM, Shah YM, Gonzalez FJ (2012) The role of peroxisome proliferator-activated receptors in carcinogenesis and chemoprevention. Nat Rev Cancer 12:181-195. doi:10.1038/nrc3214

Pohl P, Stelmach E, Welna M, Szymczycha-Madeja A (2013) Determination of the elemental composition of coffee using instrumental methods. Food Anal Methods 6:598-613. doi:10. 1007/s12161-012-9467-6

Prabhakar MM, Vasudevan K, Karthikeyan S, Baskaran N, Silvan S, Manoharan S (2012) Anti-cell proliferative efficacy of ferulic acid against 7, 12-dimethylbenz (a) anthracene induced hamster buccal pouch carcinogenesis. Asian Pac J Cancer Prev 13:5207-5211

Redeuil K et al (2011) Identification of novel circulating coffee metabolites in human plasma by liquid chromatography-mass spectrometry. J Chromatogr A 1218:4678-4688. doi:10.1016/j. chroma.2011.05.050

Rodrigues NP, Bragagnolo N (2013) Identification and quantification of bioactive compounds in coffee brews by HPLC-DAD-MS ${ }^{\mathrm{n}}$. J Food Compos Anal 32:105-115

Rodrigues NP, Toledo Benassi M, Bragagnolo N (2013) Scavenging capacity of coffee brews against oxygen and nitrogen reactive species and the correlation with bioactive compounds by multivariate analysis. Food Res Int 61:228-235. doi:10.1016/j. foodres.2013.09.028

Rosendahl AH et al (2014) Caffeine and caffeic acid inhibit growth and modify estrogen receptor (ER)- $\alpha$ and insulin-like growth factor I receptor (IGF-IR) levels in human breast cancer. Cancer Res 74:4685. doi:10.1158/1078-0432.CCR-14-1748

Saiki S et al (2011) Caffeine induces apoptosis by enhancement of autophagy via PI3K/Akt/mTOR/p70S6K inhibition. Autophagy $7: 176$

Sato $\mathrm{Y}$ et al (2011) In vitro and in vivo antioxidant properties of chlorogenic acid and caffeic acid. Int J Pharm 403:136-138. doi:10.1016/j.ijpharm.2010.09.035

Sawadogo WR, Schumacher M, Teiten MH, Dicato M, Diederich M (2012) Traditional West African pharmacopeia, plants and derived compounds for cancer therapy. Biochem Pharmacol 84:1225-1240. doi:10.1016/j.bcp.2012.07.021

Sawadogo WR, Boly R, Cerella C, Teiten MH, Dicato M, Diederich $M$ (2015) A survey of marine natural compounds and their derivatives with anti-cancer activity reported in 2012. Molecules 20:7097-7142. doi:10.3390/molecules20047097

Sbrana C, Avio L, Giovannetti M (2014) Beneficial mycorrhizal symbionts affecting the production of health-promoting phytochemicals. Electrophoresis 35:1535-1546

Schnekenburger M, Dicato M, Diederich M (2014) Plant-derived epigenetic modulators for cancer treatment and prevention. Biotechnol Adv 32:1123-1132. doi:10.1016/j.biotechadv.2014. 03.009

Schnekenburger M, Florean C, Grandjenette C, Diederich M (2015) Novel pharmaceutical approaches by natural compound-derived epigenetic regulators: epigenetic readers, writers and erasers as therapeutic targets. Curr Top Med Chem 16. doi:10.2174/ 1568026616999151013124913

Schumacher M, Kelkel M, Dicato M, Diederich M (2011) Gold from the sea: marine compounds as inhibitors of the hallmarks of cancer. Biotechnol Adv 29:531-547. doi:10.1016/j.biotechadv.2011.02.002

Shashni B, Sharma K, Singh R, Sakharkar KR, Dhillon SK, Nagasaki Y, Sakharkar MK (2013) Coffee component hydroxyl hydroquinone (HHQ) as a putative ligand for PPAR gamma and implications in breast cancer. BMC Genom 14(Suppl 5):S6. doi:10.1186/1471-2164-14-S5-S6

Shi $\mathrm{H}$ et al (2013) Chlorogenic acid reduces liver inflammation and fibrosis through inhibition of toll-like receptor 4 signaling pathway. Toxicology 303:107-114. doi:10.1016/j.tox.2012.10.025

Shim SG et al (2013) Caffeine attenuates liver fibrosis via defective adhesion of hepatic stellate cells in cirrhotic model. J Gastroenterol Hepatol 28:1877-1884. doi:10.1111/jgh.12317

Silva JA, Borges N, Santos A, Alves A (2012) Method validation for cafestol and kahweol quantification in coffee brews by HPLCDAD. Food Anal Methods 5:1404-1410

Somporn C, Kamtuo A, Theerakulpisut P, Siriamornpun S (2011) Effects of roasting degree on radical scavenging activity, phenolics and volatile compounds of Arabica coffee beans (Coffea arabica L. cv. Catimor). Int J Food Sci Technol 46:2287-2296. doi:10.1111/j.1365-2621.2011.02748.x

Sridevi V, Parvatam G (2013) Influence of altitude variation on trigonelline content during ontogeny of Coffea canephora fruit. J Food Stud 2:62-74. doi:10.5296/jfs.v2i1.3747

Styer AM, Roesch SL, Argyropoulos G (2014) Modulation of fibroblast growth factor 19 expression by bile acids, meal replacement and energy drinks, milk, and coffee. PLoS One 9:e85558. doi:10.1371/journal.pone.0085558

Tagliazucchi D, Helal A, Verzelloni E, Conte A (2012) The type and concentration of milk increase the in vitro bioaccessibility of coffee chlorogenic acids. J Agric Food Chem 60:11056-11064. doi:10.1021/jf302694a

Teiten MH, Gaascht F, Eifes S, Dicato M, Diederich M (2010) Chemopreventive potential of curcumin in prostate cancer. Genes Nutr 5:61-74. doi:10.1007/s12263-009-0152-3

Teiten MH, Gaascht F, Cronauer M, Henry E, Dicato M, Diederich M (2011) Anti-proliferative potential of curcumin in androgendependent prostate cancer cells occurs through modulation of the Wingless signaling pathway. Int J Oncol 38:603-611. doi:10. 3892/ijo.2011.905

Teiten MH, Gaascht F, Dicato M, Diederich M (2013) Anticancer bioactivity of compounds from medicinal plants used in European medieval traditions. Biochem Pharmacol 86:1239-1247. doi:10.1016/j.bcp.2013.08.007

Trachootham D, Alexandre J, Huang P (2009) Targeting cancer cells by ROS-mediated mechanisms: a radical therapeutic approach? Nat Rev Drug Discov 8:579-591. doi:10.1038/nrd2803 
Troup GJ, Navarini L, Suggi Liverani F, Drew SC (2015) Stable radical content and anti-radical activity of roasted Arabica coffee: from in-tact bean to coffee brew. PLoS One 10:e0122834. doi:10.1371/journal.pone. 0122834

Tsabar M et al (2015) Caffeine impairs resection during DNA break repair by reducing the levels of nucleases Sae2 and Dna2. Nucleic Acids Res 43:6889. doi:10.1093/nar/gkv520

Vesely MD, Kershaw MH, Schreiber RD, Smyth MJ (2011) Natural innate and adaptive immunity to cancer. Annu Rev Immunol 29:235-271. doi:10.1146/annurev-immunol-031210-101324

Vicente SJV, Queiroz YS, Gotlieb SLD, Torres EAFdS (2014) Stability of phenolic compounds and antioxidant capacity of regular and decaffeinated coffees. Braz Arch Biol Technol 57:110-118. doi:10.1590/S1516-89132014000100016

Volz N et al (2012) Effect of coffee combining green coffee bean constituents with typical roasting products on the Nrf2/ARE pathway in vitro and in vivo. J Agric Food Chem 60:9631-9641. doi:10.1021/jf302258u

Wang S, Yoon YC, Sung MJ, Hur HJ, Park JH (2012) Antiangiogenic properties of cafestol, a coffee diterpene, in human umbilical vein endothelial cells. Biochem Biophys Res Commun 421:567-571. doi:10.1016/j.bbrc.2012.04.046

Ward PS, Thompson CB (2012) Metabolic reprogramming: a cancer hallmark even warburg did not anticipate. Cancer Cell 21:297-308. doi:10.1016/j.ccr.2012.02.014

Wei F, Furihata K, Koda M, Hu F, Kato R, Miyakawa T, Tanokura M (2012a) (13)C NMR-based metabolomics for the classification of green coffee beans according to variety and origin. J Agric Food Chem 60:10118-10125. doi:10.1021/jf3033057

Wei F, Furihata K, Koda M, Hu F, Miyakawa T, Tanokura M (2012b) Roasting process of coffee beans as studied by nuclear magnetic resonance: time course of changes in composition. J Agric Food Chem 60:1005-1012. doi:10.1021/jf205315r

Welti J, Loges S, Dimmeler S, Carmeliet P (2013) Recent molecular discoveries in angiogenesis and antiangiogenic therapies in cancer. J Clin Investig 123:3190-3200. doi:10.1172/JCI70212
White MC, Peipins LA, Watson M, Trivers KF, Holman DM, Rodriguez JL (2013) Cancer prevention for the next generation. J Adolesc Health 52:S1-S7. doi:10.1016/j.jadohealth.2013.02.016

Winkler S et al (2014) Modulation of inflammatory gene transcription after long-term coffee consumption. Food Res Int 63:428-438. doi:10.1016/j.foodres.2014.05.073

Witsch E, Sela M, Yarden Y (2010) Roles for growth factors in cancer progression. Physiology 25:85-101. doi:10.1152/physiol. 00045.2009

Wright $\mathrm{G}$ et al (2013) Caffeine in floral nectar enhances a pollinator's memory of reward. Science 339:1202-1204. doi:10.1126/ science. 1228806

Yang J-S et al (2012) Chlorogenic acid induces apoptotic cell death in U937 leukemia cells through caspase-and mitochondria-dependent pathways. In Vivo 26:971-978

Yeh $\mathrm{CH}$ et al (2012) Caffeine treatment disturbs the angiogenesis of zebrafish embryos. Drug Chem Toxicol 35:361-365. doi:10. 3109/01480545.2011.627864

Yeretzian C, Pascual EC, Goodman BA (2012) Effect of roasting conditions and grinding on free radical contents of coffee beans stored in air. Food Chem 131:811-816. doi:10.1016/j.foodchem. 2011.09.048

Yu X, Bao Z, Zou J, Dong J (2011) Coffee consumption and risk of cancers: a meta-analysis of cohort studies. BMC Cancer 11:96. doi:10.1186/1471-2407-11-96

Zhao L, Su J, Li L, Chen J, Hu S, Zhang X, Chen T (2014) Mechanistic elucidation of apoptosis and cell cycle arrest induced by 5-hydroxymethylfurfural, the important role of ROS-mediated signaling pathways. Food Res Int 66:186-196. doi:10.1016/j.foodres.2014.08.051

Zwergel C, Gaascht F, Valente S, Diederich M, Bagrel D, Kirsch G (2012) Aurones: interesting natural and synthetic compounds with emerging biological potential. Nat Prod Commun 7:389-394 